\title{
МИКРОПЕРЕПИСИ НАСЕЛЕНИЯ РОССИИ: ПРОШЛОЕ, НАСТОЯЩЕЕ И БУДУЩЕЕ
}

\author{
АНАСТАСИЯ ПЬЯНКОВА, ЕКАТЕРИНА ЩЕРБАКОВА, СЕРГЕЙ ВАСИН
}

\begin{abstract}
Прослежена история трех микропереписей населения, проведенных в России в 1985, 1994 и 2015 годах. Выделены их организационно-методологические характеристики, программные особенности. Поскольку микропереписи дают большее поле для исследований по сравнению со всеобщими переписями населения, особое внимание уделено тому, какое отражение итоги микропереписей нашли в научных исследованиях и какие были получены выводы на их основе.

Более пристальное внимание уделено микропереписи населения 2015 г. (МПН-2015). Выявлень отклонения выборки МПН-2015 по регионально-территориальной структуре от постоянного населения России. Из-за значительной вариативности объема выборки по регионам пострадала репрезентативность данных по стране в иелом, наблюдается смещенность сочиальнодемографических и географических характеристик населения. Сопоставление численности $u$ структуры населения по МПН-2015 с данными текущего учета и всеобщих переписей населения, оценка возрастной аккумулячуии показали наличие серьезных проблем с качеством полученных данных, а также наличие типичных для всеобщих переписей ошибок. Акцентируется внимание на смещении в старшие возраста структуры населения по МПН-2015, что может повлиять на оценку общих показателей образования, экономической активности, заболеваемости, инвалидности, демографического состава домохозяйств и других переменных, для которых существует тесная связь с возрастом, что в целом может отразиться на востребованности данных МПН-2015. В заключении, обращаясь к опыту микропереписей и сочиально-демографических обследований в зарубежных странах, а также выборочным обследованиям Росстата по сочиально-демографическим проблемам, поставлен вопрос о перспективах развития данного метода статистико-демографического наблюдения в России.
\end{abstract}

Ключевые слова: история микропереписей населения, вопросы микропереписи, выборка, качество данныхх.

\section{ВВЕДЕНИЕ}

История, организационно-методологические и программные характеристики микропереписей населения реже попадают в фокус внимания исследователей. В связи с этим в данной работе предпринята попытка дать представление об истории микропереписей населения в России как системном виде статистического наблюдения. Предоставляя больше возможностей для исследования демографических процессов по сравнению со всеобщими переписями населения, данные микропереписей являются основой многих фундаментальных демографических работ. Поэтому одной из задач было проследить, в какой степени итоги микропереписей нашли отражение в научных исследованиях. Более пристальное внимание к микропереписи населения 2015 г. (МПН-2015) обусловливается как нововведениями программы, так и особенностями выборки. Логика данной работы хронологическая в соответствии с годами проведения трех микропереписей населения России: 1985 г. как части СССР, 1994 и 2015 г.

АНАСТАСИЯ ИвАНОВНА ПьяНКОВА (apyankova@hse.ru), НАЦИОНАЛЬНЫЙ ИССЛЕДОВАТЕЛЬСКИЙ УНИВЕРСИТЕТ «ВЫСШАЯ ШКОЛА ЭКОНОМИКИ», РОССИЯ.

ЕКАТЕРИНА МИХАЙЛОВНА ЩЕРБАКОВА (escherbakova@hse.ru), НАЦИОНАЛЬНЫЙ ИССЛЕДОВАТЕЛЬСКИЙ УНИВЕРСИТЕТ «ВЫСШАЯ ШКОЛА ЭКОНОМИКИ», РОССИЯ.

СЕРГЕЙ АЛЕКСЕЕВИЧ ВАСИН (svasin@hse.ru), НАЦИОНАЛЬНЫЙ ИССЛЕДОВАТЕЛЬСКИЙ УНИВЕРСИТЕТ «ВЫСШАЯ ШКОЛА ЭКОНОМИКИ», РОССИЯ.

ИССЛЕДОВАНИЕ ВЫПОЛНЕНО В РАМКАХ ПРОГРАММЫ ФУНДАМЕНТАЛЬНЫХ ИССЛЕДОВАНИЙ НИУ ВШЭ В 2017 Г., ПРОЕКТ ДОЛГОСРОЧНОЕ ДЕМОГРАФИЧЕСКОЕ РАЗВИТИЕ В СВЕТЕ РЕЗУЛЬТАТОВ ВСЕРОССИЙСКОЙ МИКРОПЕРЕПИСИ НАСЕЛЕНИЯ 2015 Г.».

СТАТЬЯ ПОСТУПИЛА В РЕДАКЦИЮ В МАЕ 2018 Г. 


\section{ПРОШЛОЕ: МИКРОПЕРЕПИСИ НАСЕЛЕНИЯ 1985 И 1994 ГОДОВ}

\section{Микроперепись 1985 2.}

Oпьт предществующих выборочных обследований. В 1960-е и 1970-е годы отделом статистики бюджетов ЦСУ СССР проводились бюджетные обследования доходов семей рабочих, служащих, колхозников. Отдел демографии НИИ ЦСУ СССР выступил с инициативой включения в эти обследования блока вопросов о рождаемости и брачности. С 1972 г. они стали регулярными и проводились раз в три года $(1972,1975,1978,1981$ г.), получив название «сентябрьских» по месяцу проведения. Программа этих обследований дала возможность изучать рождаемость в брачных когортах и когортах по году рождения, рассчитать вероятности рождения ребенка определенной очередности и построить таблицы брачности, в том числе по национальностям. Масштаб обследований (опрашивалось 300 350 тыс. семей) позволял получить данные по республикам СССР. Помимо этого, их достоинством было составление выборки по единой схеме и полная сопоставимость программ [Волков 2014: 183].

Организационные и методологические характеристики. В сентябре 1983 г. были приняты решение Политбюро ЦК КПСС и постановление Совета министров СССР от 1 сентября 1983 г. №865 о проведении органами государственной статистики Всесоюзного $5 \%$-ого выборочного социально-демографического обследования населения по состоянию на 2 января 1985 г., которое в последствии стали называть микропереписью по аналогии с микропереписью 1994 года (далее МПН-1985) [История... 2013: 343]. МПН-1985 должно было отразить изменения, произошедшие с момента Всесоюзной переписи населения 1979 г. (ВПН-1979), дать основу для разработки планов социально-экономического развития на 12-ю пятилетку и оценки эффективности мероприятий демографической политики по расширению помощи семьям с детьми, введенных в 1981-1983 гг.

Микроперепись проводилась в период с 2 по 11 января 1985 г., данные собирались на 0 часов 3 января. Единицами выборки послужили избирательные округа для выборов в Верховный Совет СССР. Объем выборки составил 5\% избирательных участков, на территории которых опрашивалось все постоянное население во всех союзных и автономных республиках, краях и областях, за исключением жителей труднодоступных районов Крайнего Севера и Сибири. Опрос проводили в виде личного интервью с использованием бумажных переписных листов. Число опрошенных составило около 13 млн.

Нагрузка на переписной персонал всех уровней предполагалась 500 респондентов на 1 работника в день. Помимо заполнения бланков, в отчете о подготовке и проведении МПН1985 следовало указать: затруднения, встретившиеся при подготовке опросных листов к механизированной разработке и отправке в ГВЦ ЦСУ СССР, у лиц трудоспособного возраста, занятых в домашнем и личном подсобном хозяйстве, неучащихся; затруднения, встретившиеся при проверке и кодировании ответов; характерные ошибки счетчиков, выявленные на стадии проверки и кодирования материала; число случаев незаполнения позиций бланков; трудности при кодировании данных о национальностях и использовании словаря национальностей [История... 2013: 337]. 
Программа МПН-1985 (5 разделов, 27 вопросов) преследовала две цели: сохранить преемственность с ВПН-1979 и получить более широкий круг сведений по сравнению со всеобщими переписями. Единицей наблюдения, как и в ВПН-1979, была семья.

В первый раздел «Информация о каждом респонденте» были внесены следующие нововведения по сравнению с ВПН-1979:

- учет 5 категорий брачного состояния (никогда не состоявшие в браке, состоящие в браке, вдовые, разведенные, разошедшиеся) - добавлена отдельная категория «разошедшиеся»;

- в дополнение к вопросу о числе рожденных детей спрашивали, сколько из них живы, год и месяц рождения каждого; если умер, то год смерти;

- была изменена формулировка вопроса о миграции: учет непрерывности проживания с рождения; если нет, то год прибытия и тип поселения, откуда прибыл;

- включен вопрос о доходе;

- исключены вопросы о главе семьи, родном языке, месте работы и занятии.

Для каждого состоявшего в браке (раздел «информация о браке») был предусмотрен вопрос о годе вступления в 1-й брак (без разделения на зарегистрированный или нет), причине и дате его прекращения, годе вступления во 2-ой брак. Замужним женщинам в возрасте до 45 лет (раздел «информация о рождении детей»), помимо вопросов о рождаемости, задавали вопрос о репродуктивных планах - ожидаемом числе детей, включая уже имеющихся. Этот вопрос продолжал традицию «сентябрьских» обследований (включался с 1972 г.), и позволял оценить степень реализации репродуктивных планов семей. Для выяснения эффективности государственных мер помощи семьям были предусмотрены вопросы о статусе занятости женщины и использовании отпуска по уходу за ребенком в возрасте до года и 1,5 лет.

В программе МПН-1985 был расширен блок вопросов о жилищных условиях (у молодых семей спрашивали, брали ли они беспроцентную ссуду на улучшение жилищных условий), впервые исследовали мнения населения о наиболее важных проблемах из предложенного списка, которые должны быть решены в первую очередь [Волков 2014:180198].

Затруднения по каждому блоку вопросов, с которыми столкнулись как счетчики, так и респонденты при опросе и заполнении бланков, были очерчены в статье И. Белова [1986]. Часть их была обусловлена неточностью отдельных формулировок и положений Инструкции о порядке обследования и заполнения бланков.

Публикаџия итогов. Результаты обследования по некоторым вопросам вызывали обеспокоенность и сомнения: о доходах, мнениях населения о наиболее важных проблемах, о национальном составе. Часть результатов предписывалось представлять только в агрегированном виде. Письмо ЦСУ $\mathrm{CCCP}^{1}$, предназначенное для служебного пользования, помимо рекомендации о публикации итогов по национальному составу, содержало рекомендацию не издавать статистический сборник с итогами МПН-1985 [История... 2013: 
338]. В результате публикация итогов в нескольких номерах «Вестника статистики» была, к сожалению, сокращенной, и преимущественно в относительных показателях [Итоги... 1986].

Анализ материалов. Материалы МПН-1985 были проанализированы отечественными демографами, хотя и в существенно меньшей степени, чем результаты последующей микропереписи 1994 г. (МПН-1994). Публикации посвящены в основном вопросам рождаемости и брачности, их этнической дифференциации, взаимосвязи брачности и миграции населения.

Прежде всего стоит выделить работы Л.Е. Дарского, в том числе в соавторстве с другими исследователями. Он показал, что степень ограничения рождаемости существенно различалась по национальностям (исследовали 17 национальностей), а среди народов с низкой рождаемостью (эстонцы, литовцы, латвийцы, украинцы, русские, белорусы, евреи, грузины, молдаване и татары) свыше 94\% женщин контролировали деторождение в конце 70-х - начале 80-х годов. В этой группе народов доля женщин, не контролирующих рождаемость, варьировалась от 3,6\% среди молдаванок до 0,2\% среди евреек [Darsky, Scherbov 1990: 8]. Среди этих народов динамика реальной рождаемости практически не отличалась от динамики ожидаемого числа детей, кроме грузин и молдаван, среди которых были некоторые расхождение между репродуктивными намерениями и их реализацией [Дарский 2005]. Народы с высокой рождаемостью (народы Закавказья, кроме грузин, и Средней Азии), находясь в тот период на более ранних стадиях демографического перехода, в значительно меньшей степени контролировали рождаемость. Среди армян, азербайджанцев, казахов снижение рождаемости продвинулось достаточно далеко. Доля женщин, контролирующих рождаемость, среди них была достаточно высокой $(71,9 \%$ среди азербайджанок) или находилась на среднем уровне (44,4\% среди казашек), а у киргизов, туркмен, узбеков и таджиков снижение рождаемости только началось и доля женщин, контролирующих рождаемость, была низкой: $25,7 \%$ среди киргизок, $27,3 \%$ среди туркменок, 32,0\% среди узбечек, 16,7\% среди таджичек [Darsky, Scherbov 1990]².

Результаты МПН-1985 также послужили базой для оценки демографического эффекта мер государственной политики помощи семьям с детьми, введенных в 1981-1983 гг. в три этапа в разных частях страны, начиная с тех, где рождаемость была самой низкой. Л.Е. Дарский, проведя детальный анализ взаимосвязи интергенетических интервалов и вероятности рождения детей разной очередности у женщин СССР разных категорий, в том числе различных национальностей, пришел к выводу, что рождаемость начала увеличиваться еще до того, как принятые меры могли оказать какой-либо эффект [Darsky 1994].

Г.А. Бондарской было показано, что роль культурно-национальных традиций в процессе прокреации оставалась на тот момент одной из важнейших, оказывающей решающее влияние на репродуктивное поведение женщин, и даже более важной социальной характеристикой, чем достигнутый уровень образования, занятость женщины,

${ }^{2}$ К сожалению, результаты данного исследования не были опубликованы в виде статей в научных журналах. В 1990 г. они вышли в виде препринта на английском языке [Darsky, Scherbov 1990], в 1992 г. Л.Е. Дарский докладывал о них на международном семинаре «Population of the former USSR in the 21 st century», и только в 2005 г. они частично были опубликованы на русском языке в Демоскопе [Дарский 2005]. 
характер местности проживания и др. Между тем этническая дифференциация рождаемости в СССР достигла своего пика к тому моменту и в ближайшее время должно было начаться ее снижение [Bondarskaya 1994]. Анализируя данные об ожидаемом числе детей, Г.А. Бондарская показала, что ориентация на двухдетную семью господствовала среди всех народов европейских территорий СССР.

Работы Л.Е. Дарского в соавторстве с И.П. Ильиной освещают вопросы брачности [Дарский, Ильина 1988, 1990а, 1990б]. Первые две из них посвящены нормализации процессов брачности, последующие - ее этнической дифференциации. Более поздняя работа основана на материалах двух микропереписей - 1985 и 1994 г. В ней впервые вычислены показатели брачности (первых браков) мужчин и женщин по национальностям, уровню образования и типам поселений (по данным МПН-1985 в целом для СССР за 19801984 гг., по данным МПН-1994 в целом для России за 1989-1993 гг.). Помимо этого, рассмотрены проблемы построения таблиц брачности [Дарский, Ильина 2000].

Распространению этнически смешанных семей посвящена работа А.Г. Волкова [2014: 405-431], впервые опубликованная в двух номерах «Вестника статистики» 1989 г. (№7, 8). В ней он выделяет 4 группы семей среди всех смешанных семей с одной супружеской парой и приводит наиболее распространенные сочетания национальностей в этнически смешанных супружеских парах. В целом по СССР супружеские пары, где один из супругов русский, составили 82,5\% всех смешанных супружеских пар. Наиболее распространенная группа - русско-украинские пары, однако общая картина сочетаний была весьма разнообразна. Так, из всех возможных сочетаний национальностей (1260) только $30 \%$ не были представлены в разработке итогов ни одной супружеской парой.

Отдельно стоит выделить работы Л.Р. Кузнецова, затрагивающие матримониальное и репродуктивное поведение мигрантов, а также влияние процессов миграции на эти виды поведения [Кузнецов 1990, 1992а, 1992б]. Он показал, что распространенность брачной миграции среди женщин Средней Азии в 3-4 раза выше, чем среди россиянок, в особенности в сельской местности этих республик. Для мигрантов (как мужчин, так и женщин) вероятности вступления в первый брак существенно выше, чем для немигрантов. Разделить мигрантов и немигрантов автору позволил учет непрерывности проживания с рождения в месте постоянного жительства, поэтому под немигрантами автор понимал непрерывно проживающих с рождения в месте постоянного жительства. Было показано, что чем дольше мигрантки проживают на новом месте, тем меньше их репродуктивное поведение отличается от поведения местного населения. Проживающие в городе бывшие сельские жители в своем репродуктивном поведении больше ориентированы на городские нормы этого поведения, что верно для регионов как с высокой, так и низкой миграционной подвижностью населения. Однако если мигрант выступает в роли носителя более продвинутых репродуктивных установок (с точки зрения демографического перехода), его поведение и после переезда остается гораздо более близким к репродуктивному поведению жителей той местности, откуда он переехал. Помимо этого, Л.Р. Кузнецов выявил более высокий уровень внебрачной рождаемости у мигранток по сравнению с жительницами принимающего сообщества, что дало основание автору предположить, что для некоторой части женщин именно внебрачное рождение стало причиной переезда. 


\section{Микроперепись 1994 года}

Изменение демографической ситуации в стране (сформировавшаяся естественная убыль), изменение социальной структуры общества, появление новых социальных категорий населения, интенсификация миграционных процессов, изменение их масштабов, структуры и направлений - все это в совокупности обусловило необходимость проведения новой микропереписи.

Организащионные $и$ методологические характеристики. Верховный Совет Российской Федерации 22 декабря 1992 г. принял постановление №4182-1 «О неотложных мерах по изучению населения и демографических перспектив Российской Федерации», предусматривающее проведение микропереписи в 1994 г. Она была проведена 14-23 февраля 1994 г. по состоянию на 0 часов 14 февраля. Объем выборки составил 5\% постоянного населения России каждого региона-субъекта федерации, включая временно отсутствующих, кроме Чеченской Республики и городов закрытого типа. Помимо этого не опрашивались некоторые категории населения: лица, проживающие в коллективных домохозяйствах (в домах для инвалидов и престарелых, детских домах, исправительных учреждениях, монастырях), а также военные срочной службы, их семьи и другие спецконтингенты. Основные пункты методологии формирования выборки были освещены в статье Т.М. Чернышовой [1990], однако полностью методология не была опубликована, несмотря на то, что, по мнению А.Г. Волкова, была хорошо разработана.

В отличие от МПН-1985 при формировании выборки МПН-1994 отказались от избирательных округов как единиц выборки в пользу счетных участков Всесоюзной переписи населения 1989 г. (ВПН-1989), где опрашивалось все постоянное население. Основным преимуществом такого принципа стало получение выборки, репрезентативной по географическому положению, типу поселения и численности населения административных единиц. Однако имелись и недостатки: не учитывалось изменение численности населения с момента проведения ВПН-1989 и возможность смещения выборки за счет наличия временных жителей в счетных участках ВПН-1989 [Волков 2014: 180-198].

Опрос проводили в виде личного интервью с использованием бумажных переписных листов. Число опрошенных составило около 7,4 млн человек. Средняя нагрузка на интервьюера в городской местности должна была составить 300 человек, в сельской - 250 человек [Волков 2014: 180-198].

Программа МПН-1994 (9 разделов, 49 вопросов) была ориентирована на отражение глобальных социально-экономических и демографических трансформаций, произошедших после распада СССР, и получение данных об изменениях демографической ситуации для оценки тенденций и перспектив воспроизводства населения. Проект программы широко обсуждался, был опубликован в «Вестнике статистики» [Исупов 1992]. Предусматривалось два отдельных списка вопросов: для постоянно проживающих и временно отсутствующих в домохозяйстве (см. приложение «Программа микропереписи 1994 года») 
Подробно организация и программа МПН-1994 проанализирована в работе А.Г. Волкова $[2014]^{3}$, мы остановимся на ее наиболее важных изменениях и нововведениях.

Важным было принятие за единицу наблюдения в соответствии с международными рекомендациями домохозяйства, а не семьи, как в МПН-1985 и переписях населения советского периода. В разделе блока вопросов о брачности впервые учитывалось 6 категорий брачного состояния, раздельно велся учет зарегистрированных и незарегистрированных браков, что позволило впоследствии оценить степень распространенности незарегистрированных браков в России. Вопросы о годе заключения первого брака, годе и причинах его распада, годе заключения второго брака сохранились, что позволило исследователям изучить брачные траектории когорт разных лет рождения, компенсацию прекращения брака повторными браками, в том числе незарегистрированными. В блоке вопросов о рождаемости вопрос об ожидаемом числе детей дополнялся вопросом о желаемом их числе. Вопросы о репродуктивных планах и установках задавались всем женщинам в возрасте 15-44 лет, тогда как в «сентябрьских» обследованиях и МПН-1985 - только замужним. Помимо ставших уже традиционными вопросов об общем числе рожденных живыми детей с указанием года рождения каждого ребенка, спрашивали об отдельно проживающих детях (годе и месяце отделения). Вопрос о языке был существенно расширен, впервые спрашивали не только о владении языками (родной, другой), но и о сферах их преимущественного повседневного использования (дома, в учебном заведении, на работе). Блок вопросов о миграции был дополнен для тех, кто проживает вне места своего рождения, вопросом о прежнем месте постоянного жительства, годе и причине его смены. Экономический блок вопросов также был дополнен вопросами о занятости, в том числе с целью выявления новых социальных категорий населения - безработных в соответствии с рекомендациями МОТ. Включение вопроса о доходах было признано нецелесообразным по итогам МПН-1985 [Белов 1986:42], но он был сохранен, хотя и вызвал много споров, как и при подготовке программы МПН-1985.

Публикация итогов. Разработка итогов микропереписи завершилась достаточно быстро, уже к концу 1994 г. были опубликованы первые результаты, а в 1995 г. - 8 томов сборников. Публикация материалов МПН-1994 была существенно более широкой, чем предыдущей микропереписи 1985 г. [Основные итоги... 1995]. Помимо этого, полный файл индивидуальных данных в электронном виде открыт для исследователей, что позволяет осуществлять разработку данных в любой комбинации признаков [Вишневский, Захаров 2010]. В связи с этим важно отметить вклад Е.Л. Сороко в обработку индивидуальных данных МП-1994. Им была разработаны технологии, в т. ч. компьютерные программы, и алгоритмы обработки массивов информации с индивидуальными ответами на вопросы МП1994; макеты новых и нестандартных таблиц с демографическими показателями и методы их табуляции; выполнена окончательная обработка, форматирование и оформление демографических таблиц.

Эти обстоятельства повлияли на более широкое изучение результатов МПН-1994 и круг публикаций. К ее результатам исследователи продолжают обращаться до сих пор.

3 До этого она публиковалась только в виде препринта на иностранном языке [Volkov 1999b]. 
Анализ материалов. Отметим наиболее фундаментальные работы, посвященные, как и прежде, в основном вопросам рождаемости и брачности, их взаимосвязи. Помимо этого, нововведения программы МПН-1994 позволили начать изучение домохозяйств, их структуры, этнических особенностей, а также миграции населения.

С.Я. Щербов и Х. Ван Виайнен выполнили серию исследований, используя специальную индивидуальную разработку данных МПН-1994, посвященных репродуктивной и брачной истории поколений женщин, родившихся в 1910-1934 гг. [Scherbov, van Vianen 1999] и в 1900-1960 гг. [Scherbov, van Vianen 2001]. Анализируя когортные показатели рождаемости, вероятности рождения детей разной очередности и длину интервалов между рождениями детей разной очередности, они пришли к выводу, что репродуктивное поведение женщин, рожденных в 1900-1960 гг., на протяжении длительного периода оставалось весьма стабильным. Этот вывод может служить аргументом в пользу того, что на падение рождаемости, наблюдавшееся в период проведения МПН-1994, в большей степени могло влиять изменение календаря рождений, нежели изменение реального репродуктивного поведения женщин к концу фертильного периода их жизни. Кроме того, он подтверждает то, что только показатели когортного анализа рождаемости могут отражать реальную динамику репродуктивного поведения женщин.

Так же было показано, что, хотя ни один из наблюдавшихся в России кризисов не оказал решающего влияния на процесс демографического перехода в рождаемости, политические события нередко имели глубокие краткосрочные последствия [Scherbov, van Vianen 2002]. В работе 2004 г., посвященной брачности, используя метод мультистатусных таблиц брачности, рассчитанных для мужчин и женщин в отдельности, С.Я. Щербов и Х. Ван Виайнен показали, что распространенность развода росла монотонно с достаточно низкого уровня когорт 1910 года рождения. Однако типичная восточно-европейская брачная структура, характеризуемая ранним и почти всеобщим браком, была удивительно стабильной. Революция 1917 года, последовавшие за ней события, Вторая мировая война привели к откладыванию брака. Однако даже в когортах, столкнувшихся с сильно несбалансированным брачным рынком, доля никогда не состоящих в браке была исключительно низкой [Scherbov, van Vianen 2004].

Анализируя таблицы брачности реальных поколений, рожденных в 1910-1974 гг., C.В. Захаров также показал, что в России XX века модель ранней и всеобщей брачности была очень устойчивой (к 35 годам доля женщин, когда-либо состоящих в браке, составляла 90\% и выше) [Захаров 2006]. Несмотря на то, что войны и другие катаклизмы оказывали влияние на повышение среднего возраста вступления в первый брак (наибольшим оно было для когорты 1923 года рождения - до 24,9 лет), впоследствии неизменно происходило омоложение брачности (для когорт, рожденных в 1930-1950 гг. и позже).

Материалы МПН-1994 были использованы не только в рамках когортного анализа, призванного дать ответ о долгосрочных изменениях рождаемости. Н.Б. Баркалов использовал их для анализа рождаемости по очередности рождений в условных поколениях [Barkalov 1997, 1999]. В своей последней работе, вышедшей уже после его смерти, он показывает, что изменения рождаемости в России в 1980-х и 1990-х годах в гораздо 
большей степени были связаны с изменением самого уровня рождаемости, чем с изменением календаря рождаемости [Barkalov 2005].

Трансформация брачности в России также была предметом исследования М. Миллс [Mills 2000, 2004]. Проведя международное сравнение с аналогичными процессами в Канаде и Голландии, она пришла к выводу, что брачные траектории чрезвычайно разнообразны в Канаде и Нидерландах, тогда как в России весьма однообразны, несмотря на высокую долю вдов, даже в молодых возрастах, разводов и компенсирующих их повторных браков [Mills 2004].

Исследования подтвердили гипотезу превалирования долгосрочных трендов в снижении рождаемости в начале 1990-х годов над социально-экономическим кризисом этого периода [Kharkova, Andreev 2000; Андреев, Бондарская, Харькова 2000].

Е.М. Андреев и Г.А. Бондарская изучали возможности использования данных об ожидаемом числе детей для прогноза населения и показали, что женщины одних и тех же поколений за прошедшие 9 лет между МПН-1985 и МПН-1994 незначительно изменили свои планы [Андреев, Бондарская 2000]. Наибольшие изменения характерны для молодых когорт, поэтому, как считают исследователи, сведения об ожидаемом ими числе детей следует использовать в прогнозе с осторожностью. Оптимальный вариант прогноза основан на совместном использовании показателей как для замужних, так и незамужних женщин. Последующие работы подтвердили целесообразность использования опросов женщин об ожидаемом числе детей для прогнозов рождаемости, поскольку в старших когортах (30 лет и старше) число ожидаемых детей по ответам женщин в ходе МПН-1994 г. оказалось близко к реальности в 2010 г. по итогам ВПН-2010 [Андреев, Харькова 2015: 45-46].

А.Г. Волков, занимаясь вопросами изменения семейной структуры, пришел к выводу о невосполнимости ущерба от прекращения брака [Volkov 1999] ${ }^{4}$. Было показано, что шансы на повторное вступление в брак существенно дифференцированы по полу: для мужчин прекращение первого брака на 2/3 компенсируется повторными браками через 10 лет после прекращения первого, тогда как для женщин - всего на 1/3.

А.Г. Волков показал, что распространенность незарегистрированного брака зависит от его очередности: доля незарегистрированных браков выше среди повторных браков. Помимо этого, их доля сильно варьируется по регионам страны и национальностям, она выше в сельской местности, чем в городской, и повышается к старшим возрастам (40 и старше). Использование в качестве единицы наблюдения домохозяйства позволило разработать типологию домохозяйств и впервые получить сопоставимые в международном контексте данные об их структуре. Впервые было выявлено наличие такой формы домохозяйства, как супруги, живущие раздельно (для мужчин $-3,2 \%$, для женщин - 4,6\%). Развитие этой темы нашло свое отражение в совместной публикации с Е.Л. Сороко [Волков, Сороко 1999]. В начале 2000-х годов были опубликованы работы по структуре этнических (еврейских) домохозяйств [Soroko 2001; Andreev 2001].

${ }^{4}$ Впервые работа опубликована на русском языке только в 2014 г. [Волков 2014: 432-447]. 
В когортном исследовании внутренней миграции, отражающей миграционную историю живущих поколений, Е.М. Андреев и М.В. Рахманинова [1999] установили, что для всех без исключения когорт был характерен западный миграционный дрейф.

Отдельно можно выделить работы М.С. Тольца и Е.Л. Сороко [Soroko 2001; Tolts 1996, 1997, 1998, 1999], посвященные анализу различных аспектов демографического поведения еврейского населения России на основе данных МПН-1994: распространенности смешанных браков; этнической принадлежности детей, рожденных в смешанных браках; численности, половозрастной и брачной структур еврейского населения; расселения; использования идиш как родного и второго языка еврейского населения.

Конечно, и другие исследователи обращались в разные годы к данным МПН-1994. Мы постарались осветить результаты наиболее фундаментальных работ, выполненных на ее материалах.

\section{Настоящее: микроперепись населения 2015 года}

В настоящее время микроперепись населения занимает в России промежуточное положение между всеобщими переписями населения и выборочными обследованиями в системе статического наблюдения демографических процессов Росстата. Очертив организационно-методологические и программные особенности микропереписи населения 2015 г. (МПН-2015), мы представим некоторые оценки качества данных МПН-2015, а затем выделим схожие и отличительные черты между МПН-2015 и всеобщими переписями населения и существующей системой выборочных обследований Росстата.

\section{ОРГАНИЗАЦИОННЫЕ И МЕТОДОЛОГИЧЕСКИЕ ХАРАКТЕРИСТИКИ}

В феврале 2013 г. Росстат издал приказ о проведении МПН-2015 $5^{5}$ которая была проведена с 1 по 31 октября 2015 г. (включительно). Данные собирались на 0 часов 1 октября. Официально названными целями МПН-2015 были: а) получение информации для анализа реализации мероприятий, представленных в Концепции демографической политики России до 2025 г.; б) получение данных о социально-экономическом положении до очередной всеобщей переписи населения; в) выполнение рекомендаций $\mathrm{OOH}$, апробация новых методов сбора сведений; г) корректировка сценариев для демографического прогноза; д) расширение системы показателей [Никитина 2015].

Выборка МПН-2015 была сформирована по всем субъектам Российской Федерации из территориальной выборки многоцелевого назначения на базе информационного массива ВПН-2010 и федерального статистического наблюдения «Перепись населения в Крымском федеральном округе». Единицей выборки выступали счетные участки ВПН-2010 (7,2 тыс. счетных участков), сохранялась целостность счетных участков. Фактический объем выборки составил 2154 тыс. человек или 1,5\% населения частных домохозяйств, учтенных ВПН-2010 и федеральным статистическим наблюдением «Перепись населения в Крымском

5 Приказ Росстата от 22 февраля 2013 г. №74 «О проведении федерального статистического наблюдения «Социально-демографическое наблюдение (микроперепись населения 2015 г.)». 
федеральном округе» 2014 г., или 1,5\% постоянного населения России по текущей оценке на 1 января 2016 г.

В ходе МПН-2015 учету подлежало постоянное население частных домохозяйств России, за исключением постоянно проживающих в составе коллективных домохозяйств и домохозяйств бездомных, лиц, находившихся временно (до 1 года) на территории России. Помимо этого, по сокращенной программе обследовали длительно отсутствующих членов домохозяйства, не входящих в численность постоянного населения данного региона. К ним относились: 1) лица, постоянно проживающие в России и временно выехавшие в другой регион страны или за рубеж в командировку, на работу по контрактам с российскими или иностранными фирмами или учебу на срок 1 год и более: 2) лица, проходящие срочную воинскую службу, и лица, находящихся в местах лишения свободы.

Опрос проводили в форме личного интервью с использованием планшетных компьютеров для записи ответов в электронные опросные листы и лишь в редких случаях (респондент отказывался отвечать, технические проблемы с планшетными компьютерами) использовали бумажные переписные листы, информацию с которых затем переносили на планшетные компьютеры. Средняя нагрузка на интервьюера составляла 400 респондентов. Также имелась возможность самозаполнения опросных листов в сети Интернет, но информация о том, как собирались сведения и объединялись в домохозяйства, сколько респондентов воспользовалось этой возможностью, отсутствует.

\section{ОСОБЕННОСТИ ПРОГРАММЫ}

Первоначальный проект программы был существенно шире реализованного. Он содержал 5 блоков и около 40 вопросов [Никитина 2013]. В итоге программа МПН-2015 содержала 28 вопросов (см. приложение «Программа микропереписи 2015 года»), среди которых были как стандартные блоки вопросов, хотя и сокращенные по сравнению с МПН-1994 и первоначальным проектом программы МПН-2015, так и новые вопросы.

К новому блоку можно отнести вопросы о здоровье. При подготовке программы микропереписи первоначально предполагалось широко использовать ее для оценки состояния здоровья населения, распространенности функциональных нарушений и инвалидности как в целом, так и по отдельным территориальным образованиям. В проекте программы присутствовал расширенный блок вопросов, но в итоге он был сокращен до трех: наличие хронических заболеваний, ограничивающих жизнедеятельность (да/нет); необходимость ежедневной помощи другого человека (да/нет, кто оказывает); наличие установленной группы инвалидности (да/нет, указание группы инвалидности). Расширенный блок вопросов, предлагаемый в проекте, был слишком общим. В ходе обсуждения предлагалось его изменить, сделав более сопоставимым с международной практикой исследования здоровья в рамках национальных выборочных исследований и переписей [Рамонов, Пьянкова 2014]. К сожалению, оставшиеся в переписном листе вопросы о здоровье малоинформативны, некоторые дублируют ведомственную статистику.

По сравнению с МПН-1994 были расширены блоки вопросов о гражданстве (добавлены вопросы об истории получения российского гражданства и о прежнем 
гражданстве) и миграции (добавлены вопросы о месте жительства в год ВПН-2010 и месте регистрации). Первоначально в разделе «миграция» присутствовал новый для переписей и микропереписей блок вопросов, призванный оценить маятниковую миграцию. Предполагалось выяснить место работы и/или учебы, частоту поездок, затрачиваемое время, вид используемого транспорта и время выезда. Однако эти важные для страны и особенно ряда ее регионов вопросы не вошли в окончательный вариант переписного листа.

Помимо этого, несмотря на накопленный положительный опыт выборочных обследований и предыдущих микропереписей, были сокращены два важных традиционных раздела программы: брачность и рождаемость. В итоге в разделе «рождаемость» остались вопросы только о числе рожденных детей без указания на то, сколько из них живы, сколько живут отдельно, очередности и года их рождения, месяца и года смерти, если ребенок умер, и о числе ожидаемых и желаемых детей. Однако был добавлен вопрос о факторах, влияющих на принятие решения о рождении детей, в том числе и получение «материнского капитала» (в первоначальном проекте программы отсутствовал). В разделе «брачность» учитывались только категории брачного состояния (как и прежде 6), а вопросы о годе вступления в первый брак, годе и причине его прекращения, времени вступления во второй брак отсутствовали (в первоначальном проекте программы присутствовали).

Лингвистический блок вопросов был также сокращен. Помимо родного языка и языков, которым респондент владеет, необходимо было указать языки, которыми респондент пользуется в повседневной жизни, но без сферы их использования (дома, на работе, в общеобразовательном учреждении), тогда как МПН-1994 надо было указать сферу повседневного использования языков.

\section{ОБ ИТОГАХ МПН-2015}

\section{Особенности выборки МПН-2015}

Выборка МПН-2015 должна была обеспечить возможность получения репрезентативных итогов по обобщающим демографическим и социально-экономическим характеристикам на уровне субъектов Российской Федерации и их центров, отразив основные структурные особенности населения [Доклад Росстата... 2016: 1]. При этом она имела свои территориальные особенности, которые могли отразиться на ее результатах.

Как отмечается в итоговом докладе Росстата, МПН-2015 проводилась в городских и сельских населенных пунктах на территории всех субъектов Российской Федерации, но более 9\% помещений, первоначально попавших в выборку, фактически выбыли из нее. Население 19 тыс. помещений (2\%) отказалось от участия в обследовании. Около 80 тыс. помещений $(8,1 \%)$ оказались пустующими, нежилыми или переписчикам не удалось застать дома их жителей в течение всего периода проведения обследования. В итоге 298 тыс. человек отсутствовали весь период проведения обследования или отказались от участия в нем [Доклад Росстата... 2016: 2].

Но более значимо то, что выборка МПН-2015 была существенно меньше, чем выборки предшествующих микропереписей 1994 и 1985 г. (по 5\% постоянного населения), 
и отличалась существенным отклонением от фактического размещения населения, т.е. от территориальной структуры генеральной совокупности. В методических пояснениях к итогам МПН-2015 специально оговаривается, что на сайте Росстата представлены абсолютные нераспространенные на генеральную совокупность и прямые относительные данные, не взвешенные по структуре населения генеральной совокупности. По отдельным территориальным разрезам таблицы не публикуются по причине их нерепрезентативности из-за недостаточного объема выборки [Методические пояснения... 2015].

Доля населения, обследованного в ходе МПН-2015, заметно различается по федеральным округам (таблица 1$)^{6}$. Объем выборки варьировался от $0,8 \%$ в Крымском федеральном округе до $3,0 \%$ в Южном федеральном округе (без Республики Крым и г. Севастополь, вошедших в состав обновленного Южного федерального округа в июле 2016 г.). Размах вариации доли населения, обследованного в городских и особенно в сельских населенных пунктах, шире. По городским поселениям она варьировалась от $0,7 \%$ в Крымском федеральном округе до 3,1\% в Южном федеральном округе, а по сельским поселениям - от 0,8\% Крымском федеральном округе до 4,8\% в Дальневосточном федеральном округе.

Вариация доли населения, обследованного в субъектах федерации, намного более значительна - от 0,7\% постоянного населения Республики Крым до 10,5\% постоянного населения Чукотского автономного округа. Помимо Республики Крым, мал объем выборки (не более 1\%) во всех трех городах федерального значения (Москве, Санкт-Петербурге и Севастополе) и Краснодарском крае, крупнейших по численности населения субъектов федерации (кроме Севастополя). Большие объемы выборки характерны для регионов с малочисленным населением. Помимо Чукотского автономного округа, к их числу относятся Ненецкий автономный округ (7,1\%), Еврейская автономная область $(6,6 \%)$, Магаданская область (6,1\%). Медианное значение доли обследованного населения составило 1,9\%, в центральной половине регионов она варьировалась от 1,4 до 2,3\%. В 55 субъектах федерации объем выборки превышал 1,5\%, в 30 - был ниже.

Доля населения, обследованного в городских поселениях, составила от 0,7\% в Республике Крым до 9,2\% в Чукотском автономном округе при медианном значении 1,6\%. Максимальные различия по доле обследованного населения характерны для сельских населенных пунктов: от 0,7 до 13,5\% в тех же регионах при медианном значении 2,4\%. В 76 субъектах федерации объем выборки сельского населения превысил 1,5\%.

Что касается региональных столиц или административных центров субъектов федерации, в МПН-2015 к ним относились соответствующие городские округа, численность населения которых можно сравнить с текущей оценкой численности самого города (без других поселений, входящих в городской округ), которая в ряде случаев ниже, чем городского округа. Полученная таким образом доля населения региональных центров, охваченного МПН-2015, составила от 0,5\% в Симферополе до 12,2\% в Анадыре при 
медианном значении 1,1\%. В 58 центрах субъектов федерации объем выборки оказался ниже $1,5 \%$.

Таблица 1. Численность населения, принявшего участие в МПН-2015, и постоянного населения на 1 января 2016 г. по федеральным округам (ФО)

\begin{tabular}{|c|c|c|c|}
\hline & $\begin{array}{c}\text { Постоянное население } \\
\text { на } 01.01 .2016, \\
\text { человек } \\
\end{array}$ & $\begin{array}{c}\text { Население, обследованное в } \\
\text { ходе МПН-2015, } \\
\text { человек }\end{array}$ & $\begin{array}{c}\text { Доля } \\
\text { обследованного } \\
\text { населения, \% } \\
\end{array}$ \\
\hline \multicolumn{4}{|c|}{ Городское и сельское население } \\
\hline Российская Федерация & 146544710 & 2154254 & 1,5 \\
\hline Центральный ФО & 39104319 & 547720 & 1,4 \\
\hline Северо-Западный ФО & 13853694 & 228087 & 1,6 \\
\hline Южный ФО & 14044580 & 426075 & 3,0 \\
\hline Северо-Кавказский ФО & 9718001 & 167509 & 1,7 \\
\hline Приволжский ФО & 29673644 & 299725 & 1,0 \\
\hline Уральский ФО & 12308103 & 146207 & 1,2 \\
\hline Сибирский ФО & 19324031 & 178195 & 0,9 \\
\hline Дальневосточный ФО & 6194969 & 143175 & 2,3 \\
\hline Крымский ФО & 2323369 & 17561 & 0,8 \\
\hline \multicolumn{4}{|c|}{ Городское население } \\
\hline Российская Федерация & 108657433 & 1414547 & 1,3 \\
\hline Центральный ФО & 32055953 & 384672 & 1,2 \\
\hline Северо-Западный ФО & 11657955 & 163232 & 1,4 \\
\hline Южный ФО & 8836149 & 272820 & 3,1 \\
\hline Северо-Кавказский ФО & 4772186 & 120291 & 2,5 \\
\hline Приволжский ФО & 21242843 & 189932 & 0,9 \\
\hline Уральский ФО & 9978692 & 96365 & 1,0 \\
\hline Сибирский ФО & 14077572 & 106172 & 0,8 \\
\hline Дальневосточный ФО & 4681585 & 70963 & 1,5 \\
\hline Крымский ФО & 1354498 & 10100 & 0,7 \\
\hline \multicolumn{4}{|c|}{ Сельское население } \\
\hline Российская Федерация & 37887277 & 739707 & 2,0 \\
\hline Центральный ФО & 7048366 & 163048 & 2,3 \\
\hline Северо-Западный ФО & 2195739 & 64855 & 3,0 \\
\hline Южный ФО & 5208431 & 153255 & 2,9 \\
\hline Северо-Кавказский ФО & 4945815 & 47218 & 1,0 \\
\hline Приволжский ФО & 8430801 & 109793 & 1,3 \\
\hline Уральский ФО & 2329411 & 49842 & 2,1 \\
\hline Сибирский ФО & 5246459 & 72023 & 1,4 \\
\hline Дальневосточный ФО & 1513384 & 72212 & 4,8 \\
\hline Крымский ФО & 968871 & 7461 & 0,8 \\
\hline
\end{tabular}

Примечание: В таблицах данные приводятся в разбивке по федеральным округам, существовавшим до июля 2016 г.

Источники: [Численность населения... 2017; Таблицы с итогами ... 2015].

Таким образом, большие объемы выборки характерны для территорий с относительно малочисленным населением, что, казалось бы, вполне оправдано с точки зрения обеспечения репрезентативности итогов. Однако это привело к довольно значительным искажениям регионально-территориальной структуры обследованного населения в целом. Отметим, что при проведении МПН-1994 вариация объема выборки была менее значительной - от 4,7\% в Калининградской области и Ханты-Мансийском автономном округе до 6,4\% в Чукотском автономном округе [Основные итоги... 1995].

Из-за существенных различий в объемах выборки по регионам в общей выборке доля населения одних регионов заметно выше, чем в генеральной совокупности, а других - 
заметно ниже. Это наглядно видно на уровне федеральных округов. Доля населения, обследованного в Южном федеральном округе, в 2 раза больше, чем в постоянном населении России, в Дальневосточном федеральном округе - в 1,6 раза. Доля населения, обследованного в Крымском федеральном округе, напротив, почти вдвое ниже (таблица 2). Более значительно искажена территориальная структура населения, обследованного в сельских населенных пунктах.

Таблица 2. Размещение населения, принявшего участие в МПН-2015, и постоянного населения на 1 января 2016 г. по федеральным округам (ФО)

\begin{tabular}{|c|c|c|c|c|}
\hline & \multirow{2}{*}{$\begin{array}{c}\text { Постоянное } \\
\text { население на } \\
01.01 .2016 \\
\% \\
\end{array}$} & \multirow{2}{*}{$\begin{array}{c}\text { Обследовано в } \\
\text { ходе МПН-2015 } \\
\%\end{array}$} & \multicolumn{2}{|c|}{$\begin{array}{c}\text { Отклонение доли обследованного } \\
\text { населения от доли постоянного населения } \\
(П Н)\end{array}$} \\
\hline & & & процентных пунктов & $\%(\Pi H=100)$ \\
\hline \multicolumn{5}{|c|}{ Городское и сельское население } \\
\hline Российская Федерация & 100 & 100 & - & - \\
\hline Центральный ФО & 26,7 & 25,4 & $-1,3$ & 95 \\
\hline Северо-Западный ФО & 9,5 & 10,6 & 1,1 & 111 \\
\hline Южный ФО & 9,6 & 19,8 & 10,2 & 206 \\
\hline Северо-Кавказский ФО & 6,6 & 7,8 & 1,2 & 118 \\
\hline Приволжский ФО & 20,2 & 13,9 & $-6,3$ & 69 \\
\hline Уральский ФО & 8,4 & 6,8 & $-1,6$ & 81 \\
\hline Сибирский ФО & 13,2 & 8,3 & $-4,9$ & 63 \\
\hline Дальневосточный ФО & 4,2 & 6,6 & 2,4 & 158 \\
\hline Крымский ФО & 1,6 & 0,8 & $-0,8$ & 51 \\
\hline \multicolumn{5}{|c|}{ Городское население } \\
\hline Российская Федерация & 100,0 & 100,0 & - & - \\
\hline Центральный ФО & 29,5 & 27,2 & $-2,3$ & 92 \\
\hline Северо-Западный ФО & 10,7 & 11,5 & 0,8 & 108 \\
\hline Южный ФО & 8,1 & 19,3 & 11,2 & 237 \\
\hline Северо-Кавказский ФО & 4,4 & 8,5 & 4,1 & 193 \\
\hline Приволжский ФО & 19,6 & 13,4 & $-6,2$ & 69 \\
\hline Уральский ФО & 9,2 & 6,8 & $-2,4$ & 74 \\
\hline Сибирский ФО & 13,0 & 7,5 & $-5,5$ & 58 \\
\hline Дальневосточный ФО & 4,3 & 5,0 & 0,7 & 117 \\
\hline Крымский ФО & 1,2 & 0,7 & $-0,5$ & 57 \\
\hline \multicolumn{5}{|c|}{ Сельское население } \\
\hline Российская Федерация & 100,0 & 100,0 & - & - \\
\hline Центральный ФО & 18,6 & 22,0 & 3,4 & 119 \\
\hline Северо-Западный ФО & 5,8 & 8,8 & 3,0 & 151 \\
\hline Южный ФО & 13,7 & 20,7 & 7,0 & 151 \\
\hline Северо-Кавказский ФО & 13,1 & 6,4 & $-6,7$ & 49 \\
\hline Приволжский ФО & 22,3 & 14,8 & $-7,5$ & 67 \\
\hline Уральский ФО & 6,1 & 6,7 & 0,6 & 110 \\
\hline Сибирский ФО & 13,8 & 9,7 & $-4,1$ & 71 \\
\hline Дальневосточный ФО & 4,0 & 9,8 & 5,8 & 244 \\
\hline Крымский ФО & 2,6 & 1,0 & $-1,5$ & 39 \\
\hline
\end{tabular}

Источники: [Численность населения... 2017; Таблицы с итогами... 2015].

На уровне субъектов федерации наибольшие отклонения доли населения в выборке от генеральной совокупности характерны, с одной стороны, для Республики Крым и г. Москвы (в 2 раза меньше), а с другой - для Чукотского автономного округа (в 6 раз больше).

В результате выборка оказалась существенно искаженной по соотношению городского и сельского населения: если по текущей оценке Росстата на 1 января 2016 г. 
доля городского населения России (с учетом Крыма) составляла 74,1\%, то среди населения, принявшего участие в МПН-2015, - 65,7\% (таблица 3). Отметим, что по данным МПН-1994 доля городского населения в выборке была такой же, что и в генеральной совокупности 73\% [Основные итоги... 1995: 6-7]. По доле городского населения наибольшее соответствие выборки генеральной совокупности отмечается в Крымском (99\%) и Южном (102) федеральных округах, наименьшее - в Северо-Кавказском (146\%) и Дальневосточном (66\%). По доле сельского населения, более малочисленного, чем городского во всех федеральных округах, кроме Северо-Кавказского, расхождения еще больше.

Таблица 3. Соотношение городского и сельского населения, принявшего участие в МПН-2015, и постоянного населения на 1 января 2016 г. по федеральным округам (ФО)

\begin{tabular}{|c|c|c|c|c|c|c|c|c|}
\hline & \multicolumn{2}{|c|}{$\begin{array}{c}\text { Доля городского } \\
\text { населения }\end{array}$} & \multicolumn{2}{|c|}{$\begin{array}{c}\text { Отклонение } \\
\text { обследованного } \\
\text { населения от } \\
\text { постоянного (ПН) } \\
\text { по доле } \\
\text { городского } \\
\text { населения }\end{array}$} & \multicolumn{2}{|c|}{$\begin{array}{c}\text { Доля сельского } \\
\text { населения }\end{array}$} & \multicolumn{2}{|c|}{$\begin{array}{c}\text { Отклонение } \\
\text { обследованного } \\
\text { населения от } \\
\text { постоянного (ПН) } \\
\text { по доле сельского } \\
\text { населения }\end{array}$} \\
\hline & $\begin{array}{c}01.01 . \\
2016\end{array}$ & $\begin{array}{c}\text { МПН- } \\
2015\end{array}$ & пП & $\%$ к ПН & $\begin{array}{c}01.01 . \\
2016\end{array}$ & $\begin{array}{c}\text { МПН- } \\
2015\end{array}$ & ПП & $\%$ \\
\hline Российская Федерация & 74,1 & 65,7 & $-8,4$ & 89 & 25,9 & 34,3 & 8,4 & 133 \\
\hline Центральный ФО & 82,0 & 70,2 & $-11,8$ & 86 & 18,0 & 29,8 & 11,8 & 165 \\
\hline Северо-Западный ФО & 84,2 & 71,6 & $-12,6$ & 85 & 15,8 & 28,4 & 12,6 & 180 \\
\hline Южный ФО & 62,9 & 64,0 & 1,1 & 102 & 37,1 & 36,0 & $-1,1$ & 97 \\
\hline Северо-Кавказский ФО & 49,1 & 71,8 & 22,7 & 146 & 50,9 & 28,2 & $-22,7$ & 55 \\
\hline Приволжский ФО & 71,6 & 63,4 & $-8,2$ & 89 & 28,4 & 36,6 & 8,2 & 129 \\
\hline Уральский ФО & 81,1 & 65,9 & $-15,2$ & 81 & 18,9 & 34,1 & 15,2 & 180 \\
\hline Сибирский ФО & 72,9 & 59,6 & $-13,3$ & 82 & 27,1 & 40,4 & 13,3 & 149 \\
\hline Дальневосточный ФО & 75,6 & 49,6 & $-26,0$ & 66 & 24,4 & 50,4 & 26,0 & 207 \\
\hline Крымский ФО & 58,3 & 57,5 & $-0,8$ & 99 & 41,7 & 42,5 & 0,8 & 102 \\
\hline
\end{tabular}

Источники: [Численность населения... 2017; Талицы с итогами... 2015].

Отмеченные отклонения выборки МПН-2015 по регионально-территориальной структуре от постоянного населения России заставляют с определенной осторожностью относиться к полученным результатам. Росстат не приводит данные МПН-2015, взвешенные по территориальной структуре фактического населения, однако представил «Сводные результаты оценки репрезентативности блоков таблиц с итогами микропереписи населения 2015 года» [Сводные результаты... 2015]. Оценка репрезентативности произведена для всех опубликованных на сайте таблиц по всем территориальным разрезам, включая субъекты федерации и их центры в разбивке на городское и сельское население. Отметим, что даже для уровня Российской Федерации в целом некоторые данные по миграции (таблицы 07-2, 07-6, 07-10), национальности (10-2) и временно отсутствующим (11-02, 11-03, 11-05) нерепрезентативны.

\section{ОСОБЕННОСТИ ВОЗРАСТНОЙ СТРУКТУРЫ НАСЕЛЕНИЯ, ОПРОШЕННОГО В МИКРОПЕРЕПИСИ, В СРАВНЕНИИ С ТЕКУЩИМИ ОЦЕНКАМИ РОССТАТА}

Проблеме оценки качества итогов микропереписей, как и всеобщих переписей, до сих пор 
уделяется недостаточное внимание. Для такой оценки возможно привлечение демографических методов: сопоставление численности и структуры населения с данными текущего учета населения, оценка возрастной аккумуляции, сопоставление с данными предыдущих переписей населения, сопоставление с иными, в том числе ведомственными, источниками.

Особенности формирования выборки МПН-2015 сказались на возрастной структуре населения: по микропереписи она заметно старше, чем по текущей оценке Росстата. Согласно последней средний возраст каждой из групп населения примерно на год ниже, чем по микропереписи (таблица 4). Завышение МПН-2015 среднего возраста на один год следует признать значительным и по отношению к приросту показателя в 2015 г. (лишь 0,1 года), и по отношению к его динамике в последние годы и в ближайшей перспективе. Так, прирост среднего возраста на один год последний раз занял 8-9 лет (в 2006-2007 гг. он был на год меньше, чем в 2015 г.), а по среднему варианту прогноза Росстата ожидается, что показатель увеличится до значений, зафиксированных в МПН-2015, в 2022-2024 гг.

Таблица 4. Средний возраст населения по МПН-2015 и текущим оценкам населения, лет

\begin{tabular}{|c|c|c|c|c|c|c|c|c|c|}
\hline & \multicolumn{3}{|c|}{$\begin{array}{c}\text { Все } \\
\text { население }\end{array}$} & \multicolumn{3}{|c|}{$\begin{array}{l}\text { Городское } \\
\text { население }\end{array}$} & \multicolumn{3}{|c|}{$\begin{array}{c}\text { Сельское } \\
\text { население }\end{array}$} \\
\hline & 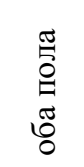 & 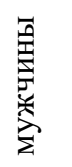 & 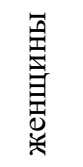 & 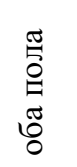 & 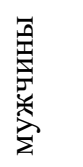 & 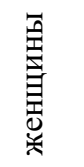 & $\begin{array}{l}\frac{\pi}{5} \\
\stackrel{0}{0} \\
\overparen{0} \\
\stackrel{0}{0}\end{array}$ & $\begin{array}{l}\text { 恶 } \\
\text { 空 } \\
\text { 帘 }\end{array}$ & 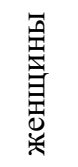 \\
\hline Текущая оценка на 01.01.2015 & 39,5 & 36,7 & 41,9 & 39,5 & 36,7 & 41,9 & 39,4 & 36,9 & 41,7 \\
\hline МПН-2015 & 40,6 & 37,7 & 43,1 & 40,7 & 37,6 & 43,1 & 40,6 & 37,8 & 43,0 \\
\hline Текущая оценка на 01.10.2015 (расчет) & 39,6 & 36,8 & 41,9 & 39,6 & 36,7 & 42,0 & 39,5 & 37,0 & 41,8 \\
\hline Текущая оценка на 01.01.2016 & 39,6 & 36,8 & 42,0 & 39,6 & 36,8 & 42,0 & 39,5 & 37,0 & 41,8 \\
\hline \multicolumn{10}{|c|}{ Разность между данными МПН-2015 и текущими оценками } \\
\hline 01.01 .2015 & 1,1 & 1,0 & 1,2 & 1,2 & 0,9 & 1,2 & 1,2 & 0,9 & 1,3 \\
\hline 01.10 .2015 (расчет) & 1,0 & 0,9 & 1,2 & 1,1 & 0,9 & 1,1 & 1,1 & 0,8 & 1,2 \\
\hline 01.01 .2016 & 1,0 & 0,9 & 1,1 & 1,1 & 0,8 & 1,1 & 1,1 & 0,8 & 1,2 \\
\hline
\end{tabular}

Примечание: Расчет текущей оченки населения на 01.10.2015 есть взвешенная средняя населения на 01.01.2015 и 01.01.2016, где в качестве весов использовалась доля года до и после 1 октября 2015 ح.

Источники: [Таблищь с итогами... 2015; Численность населения... 2015, 2016].

Смещение оценки возрастной композиции населения в старшие возраста иллюстрирует сравнение пропорций трех возрастных групп: по МПН-2015 доля пожилого населения значимо выше (таблица 5). Отклонения от текущей оценки пропорций трех возрастных групп особенно велики в городском населении, при этом сдвиг в старшие возраста и гораздо сильнее, чем в селе, и происходит преимущественно за счет доли населения в возрасте 15-59 лет, тогда как в селе - за счет доли детей. Что касается различий по полу, основное из них это то, что в женском населении доля детей занижена сильнее, чем в мужском. Более того, у сельских женщин возрастная композиция сместилась в старшие возраста только за счет доли населения в возрасте до 15 лет, в то время как у городских мужчин - только за счет населения в возрасте 15-59 лет. 
Более детально проанализировать особенности смещения позволяет отношение доли населения по МПН-2015 к доле населения по текущей оценке по однолетним возрастным группам на рисунке 1. За исключением отмеченных выше различий, характер смещения одинаков у мужчин и женщин, в городе и селе. Из рисунка 1 видно, что при МПН-2015 недоучтены дети самого раннего возраста, в особенности младенцы и годовалые малыши, доля которых занижена на 10-20\%. Почти на ту же величину, что и в интервале 0-4 года, занижена доля самой мобильной части населения в возрасте от 18 до 24 лет. В последующих возрастах различия в возрастной композиции населения между МПН-2015 и текущей оценкой убывают, а после 50 лет доля населения по МПН-2015 становится выше, чем по текущей оценке, причем после 55 лет эти различия весьма значительны.

Таблица 5. Структура населения по МПН-2015 и текущим оценкам населения, \%

\begin{tabular}{|c|c|c|c|c|c|c|c|c|c|}
\hline \multirow{2}{*}{$\begin{array}{l}\text { Дата текущей } \\
\text { оценки населения }\end{array}$} & \multicolumn{3}{|c|}{ Все население } & \multicolumn{3}{|c|}{ Городское население } & \multicolumn{3}{|c|}{ Сельское население } \\
\hline & $0-14$ & $15-59$ & $60+$ & $0-14$ & $15-59$ & $60+$ & $0-14$ & $15-59$ & $60+$ \\
\hline \multicolumn{10}{|c|}{ Оба пола } \\
\hline 01.01 .2015 & 16,7 & 63,5 & 19,9 & 15,9 & 64,3 & 19,8 & 18,8 & 61,0 & 20,2 \\
\hline МПН-2015 & 16,7 & 61,3 & 22,0 & 16,0 & 61,9 & 22,1 & 18,0 & 60,2 & 21,8 \\
\hline 01.01 .2016 & 17,0 & 62,6 & 20,3 & 16,4 & 63,4 & 20,2 & 19,0 & 60,3 & 20,7 \\
\hline 01.10.2015 (расчет) & 17,0 & 62,8 & 20,2 & 16,3 & 63,6 & 20,1 & 18,9 & 60,5 & 20,6 \\
\hline \multicolumn{10}{|c|}{ Мужчины } \\
\hline 01.01 .2015 & 18,5 & 66,5 & 15,0 & 17,9 & 67,3 & 14,9 & 20,1 & 64,5 & 15,4 \\
\hline МПН-2015 & 18,8 & 64,3 & 16,9 & 18,3 & 64,7 & 17,0 & 19,7 & 63,4 & 16,9 \\
\hline 01.01 .2016 & 18,9 & 65,7 & 15,4 & 18,4 & 66,4 & 15,3 & 20,2 & 63,8 & 16,0 \\
\hline 01.10.2015 (расчет) & 18,8 & 65,9 & 15,3 & 18,2 & 66,6 & 15,2 & 20,2 & 64,0 & 15,9 \\
\hline \multicolumn{10}{|c|}{ Женшины } \\
\hline 01.01 .2015 & 15,1 & 60,8 & 24,1 & 14,3 & 61,8 & 23,9 & 17,7 & 57,8 & 24,6 \\
\hline МПН-2015 & 14,9 & 58,9 & 26,2 & 14,1 & 59,6 & 26,3 & 16,5 & 57,4 & 26,1 \\
\hline 01.01 .2016 & 15,5 & 60,0 & 24,5 & 14,7 & 60,9 & 24,4 & 17,8 & 57,1 & 25,1 \\
\hline 01.10 .2015 (расчет) & 15,4 & 60,2 & 24,4 & 14,6 & 61,2 & 24,2 & 17,8 & 57,3 & 24,9 \\
\hline
\end{tabular}

Источники: [Таблицы с итогами... 2015; Численность населения...2015, 2016].

Население по МПН-2015 в отличие от текущей оценки населения не включает членов коллективных домохозяйств (пенитенциарной системы, армейских казарм, интернатных учреждений, медицинских и социальных учреждений с длительным уходом за тяжело больными людьми, домов для престарелых людей и др.). По переписи 2010 г. в институциональном населении насчитывалось почти 2 млн человек $(1,3 \%)$. В нем преобладали мужчины (1,6 млн), половина которых находилась в возрасте от 18 до 27 лет, где как раз наблюдается сильный «дефицит» населения по МПН-2015 относительно текущей оценки. У женщин распределение институционального населения по возрасту не имела таких радикальных особенностей, да и доля проживающих в коллективных домохозяйствах составляла всего $0,4 \%$.

Чтобы примерно оценить влияние институционального населения на расхождения между возрастной композицией по МПН-2015 и по текущей оценке, мы скорректировали последнюю, построив ее без учета институционального населения. Коррекция не внесла ничего нового для женского населения, но для мужского населения почти устранила расхождения в возрастах от 23 до 28 лет, снизила избыток населения в старших возрастах и в целом уменьшила расхождения в оценке пропорций трех возрастных групп. Общий характер отклонений тем не менее остался неизменным, это означает, что сдвиг в старшие возраста населения по МПН-2015 должен объясняться чем-то другим. 


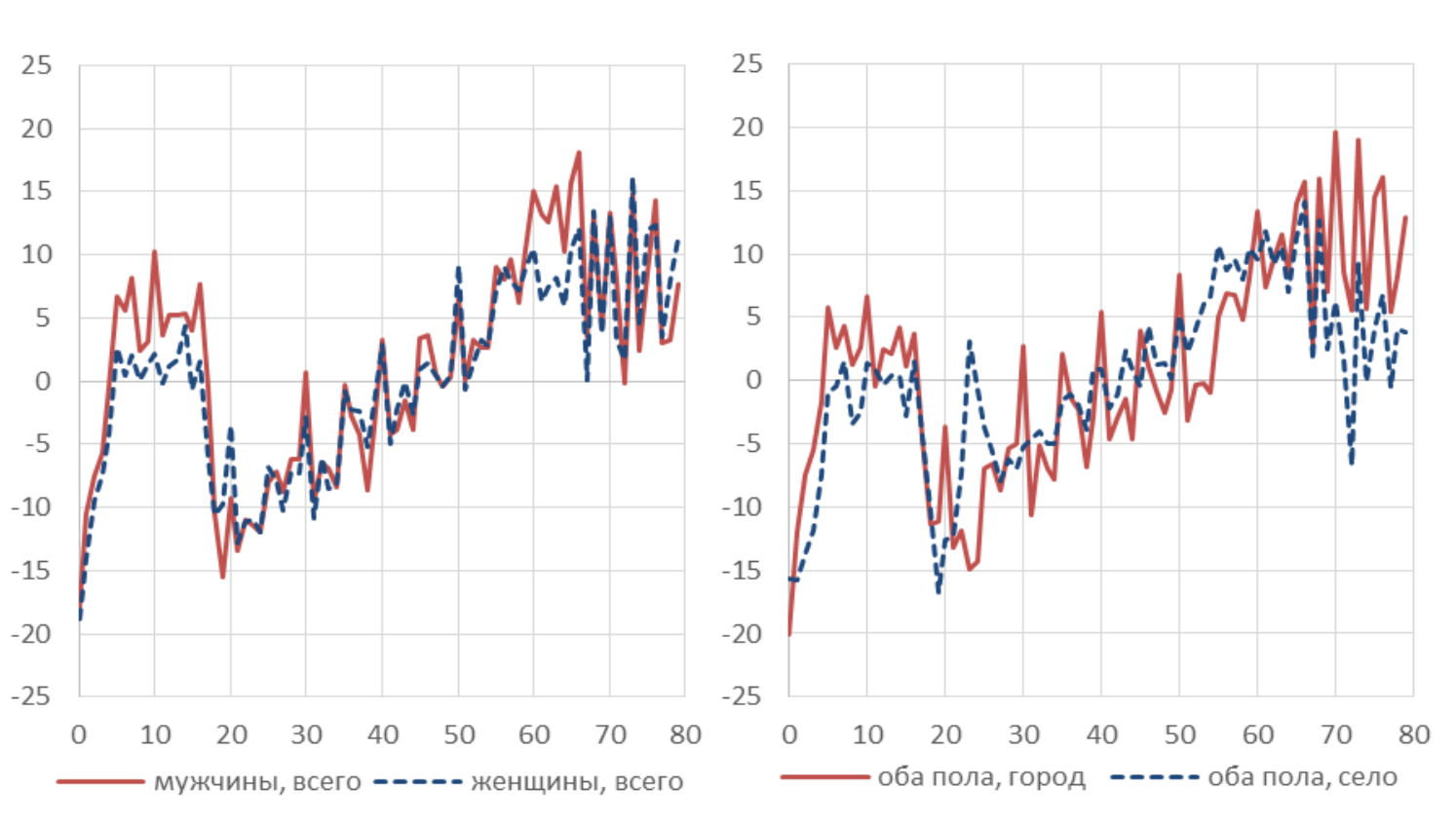

Рисунок 1. Относительная разность в долях населения между данными МПН-2015 и текущей оценкой на дату переписи по однолетним возрастным группам по полу и месту жительства, 0-79 лет, \%

Источники: [Численность населения... 2015; 2016; База микроданных... 2015].

\section{ВОЗРАСТНАЯ АККУМУЛЯЦИЯ}

Заметная на рисунке 1 аккумуляция в возрастах, оканчивающихся на 0 и 5, указывает на проблему качества данных МПН-2015 о возрастном составе населения. Аккумуляция свойственна также всеобщим переписям 2002 и 2010 г., для которых коэффициент возрастной аккумуляции Уипла составил 2,8 и 3,0, соответственно [Андреев 2012]. По МПН-2015 этот показатель по населению в целом превысил 6. Проблема свойственна в большей степени городскому населению, где значения показателя приближаются к критическому уровню (таблица 6).

Таблица 6. Коэффициент возрастной аккумуляции Уипла по МПН-2015 и текущей оценке населения, на 100

\begin{tabular}{l|c|c|c}
\hline Группа населения & МПН-2015 & Оценка на 01.10.2015 (расчетная) & Оценка на 01.01.2016 \\
\hline & \multicolumn{3}{|c}{ Все население } \\
Оба пола & 6,3 & 2,5 & 3,5 \\
Мужчины & 6,8 & 2,6 & 3,6 \\
Женщины & 5,9 & 2,4 & 3,4 \\
& & Городское население & 4,0 \\
Оба пола & 8,3 & 3,8 & 4,2 \\
Мужчины & 8,9 & 2,7 & 3,8 \\
Женщины & 7,8 & Сельское население & 2,1 \\
Оба пола & 2,3 & 1,5 & 2,1 \\
Мужчины & 2,7 & 1,5 & 2,0 \\
Женщины & 2,0 & & \\
\hline
\end{tabular}

Источники: [База микроданных... 2015; Численность населения... 2016]. 
В прошлом возрастная аккумуляция проистекала из-за неграмотности населения и плохой системы учета рождений, поэтому естественно, что в сельском населении она была значительно выше. В современной России причины иные. Уровень образования населения в городах выше, чем в селах, в средних возрастах выше, чем в пожилых, но странным образом в более образованных группах населения информация о возрасте наименее точна. Можно предложить ряд гипотез, объясняющих такую ситуацию, но этот вопрос заслуживает отдельного изучения. Однако даже если население намеренно искажает свой возраст, а организация МПН-2015 и качество интервьюирования безупречны, возрастная аккумуляция свидетельствует о невысоком качестве данных по городскому населению и населению в целом.

\section{СОПОСТАВЛЕНИЕ С ДАННЫМИ ПРЕДЫДУЩИХ ВСЕОБЩИХ ПЕРЕПИСЕЙ НАСЕЛЕНИЯ}

Микроперепись - выборочное наблюдение и этим отличается от обычных переписей населения. Тем не менее характер отклонений в возрастной структуре от текущих оценок невольно заставляет проводить параллели с типичными ошибками переписей 2002 и 2010 г. Помимо рассмотренной выше возрастной аккумуляции, микропереписи может быть свойственна такая ошибка, как недоучет детей ранних возрастов.

Определенное мнение о причинах недоучета детей в возрастах 0-3 года в последних переписях нам неизвестно. Сомнительно, что недоучет возникает из-за переучета числа рождений, и более чем сомнительно, что из-за эмиграции [Мкртчян 2012]. На примере Москвы, где по переписи 2010 г. расхождения были максимальными, показано, что эти расхождения не могут быть объяснены никакими естественными процессами, такими как смертность или эмиграция матерей с детьми [Андреев 2012]. К неестественным причинам недоучета детей до 4 лет можно отнести запаздывание регистрации таких детей в административных источниках данных, к которым обращается перепись в случае недоступности домохозяйства для опроса. Для МПН-2015 такое объяснение не подходит. Взамен можно предположить, что свою роль здесь играет значительный недоучет населения репродуктивных возрастов. Правда, в этом случае недоучет детей, как представляется, должен быть равномернее, чем на рисунке 1. Поэтому можно допустить, что в силу каких-то причин действует закономерность: чем младше малыши, тем менее доступны домохозяйства их родителей для обследования.

Еще одна типичная ошибка последних переписей - завышение численности пожилых - объясняется двойным учетом [Мкртчян 2012] и завышением возраста при ответе на вопрос о годе рождения [Андреев 2012]. Первое к МПН-2015 не относится. Второе свойственно самым старшим возрастам и может играть лишь скромную роль в столь значительном сдвиге населения в старшие возраста. Поскольку речь идет о пропорциях возрастных групп и относительные разности на рисунке 1 последовательно нарастают от двадцатилетних к шестидесятилетним, более правдоподобно, что этот сдвиг носит систематический характер и объясняется спецификой формирования выборочной совокупности МПН-2015, и, в первую очередь, ее территориальными особенностями: смещенностью выборки в сторону сельского населения и заниженного представительства в 
составе опрошенных населения крупных городов [Андреев, Захаров 2017]. Другие рассмотренные выше гипотезы или, например, гипотеза о том, что двойной учет в ВПН2010 в некоторых возрастных группах спустя пять лет привел к тому, что пропорции постаревших на пять лет возрастных когорт в МПН-2015 оказались слишком низки, могут быть верны в отношении отдельных возрастных групп, но не могут объяснить картину в целом.

Смещенная в старшие возраста композиция населения по МПН-2015 может влиять на оценку показателей, для которых существует тесная связь с возрастом, включая образование, экономическую активность, заболеваемость, инвалидность и др. В некоторых уже проведенных исследованиях с использованием результатов МПН-2015 на эти проблемы обращается внимание. Было показано влияние выборочной ошибки за счет неравномерности выборки на показатели смертности по уровню образования для некоторых регионов (Москва, Санкт-Петербург, Московская и Ленинградская области), где доля лиц с высшим образованием высока, тогда как в МПН-2015 их доля существенно ниже средней по стране [Андреев, Никитина, Харькова 2017: 64]. В работе Е.М. Андреева и С.В. Захарова показано, что доля женщин с большим числом рожденных детей и среднее число рожденных детей в выборочной совокупности женщин, принявших участие в МПН-2015, оказалось выше, чем, если бы выборка во всех регионах была одинаковой [Андреев, Захаров 2017].

\section{СОВРЕМЕННОЕ МЕСТО МПН-2015 В СИСТЕМЕ СТАТИЧЕСКОГО НАБЛЮДЕНИЯ ДЕМОГРАФИЧЕСКИХ ПРОЦЕССОВ РОССТАТА}

Чтобы позиционировать МПН-2015 в системе современного статистического учета, целесообразно выделить общие и отличительные аспекты по сравнению с системой выборочных обследований Росстата ${ }^{7}$, проводимых с 2011 г. В рамках изучения условий проживания и образа жизни населения проводится 7 выборочных обследований, в рамках изучения интеграционных процессов на рынке труда - 3. Они различаются по тематике, периодичности проведения (от ежегодных до проводимых раз в 5 лет) и числу обследуемых домохозяйств (от 10 до 160 тыс.). Из 10 обследований наиболее целесообразно сравнить МПН-2015 с пятью наиболее схожими по тематике выборочными обследованиями: условий жизни населения; репродуктивных планов населения; поведенческих факторов, влияющих на здоровье; рациона питания; доходов населения и участия в социальных программах. ${ }^{8}$

Вопросы МПН-2015 о поле, возрасте, семейном положении, наивысшем достигнутом уровне образования универсальны и характерны для всех указанных обследований. Однако в формулировке вопросов и широте блоков вопросов имеются существенные различия, даже в таком вопросе, как возраст. Например, в микропереписи вопрос о возрасте задается в виде вопроса о дате рождения, а число исполнившихся лет определяется по таблице, что является более точным подходом определения возраста, тогда ${ }^{7}$ В 2010 г. было принято постановление Правительства РФ от 27 ноября 2010 г. №946 «Об организации в Российской Федерации системы федеральных статистических наблюдений
по социально-демографическим проблемам и мониторинга экономических потерь от смертности, заболеваемости и инвалидизации населения».
${ }^{8}$ «Комплексное наблюдение условий жизни населения» (КОУж), «Выборочное наблюдение репродуктивных планов населения», «Выборочное наблюдение поведенческих факторов,
влияющих на состояние здоровья населения», «Выборочное наблюдение рациона питания населения», «Выборочное наблюдение доходов населения и участия в социальных
программах». 
как в «Комплексном наблюдении условий жизни населения» (КОУЖ) спрашивается только о числе исполнившихся лет. Блок вопросов о семейном положении в КОУЖ расширен вопросом о совместном проживании супругов, что позволяет выделить зарегистрированных супругов, проживающих отдельно, в отличие от микропереписи и всеобщих переписей, и причинах отдельного их проживания. Этот блок вопросов дополнен вопросами о числе, причинах, месте отдельного проживания детей. Обследование репродуктивных планов также позволяет выделить пары разошедшиеся, но ранее состоящие в зарегистрированном браке и не разведенные официально. В остальных обследованиях выделяются те же категории семейного положения, что и в МПН-2015.

Среди общих черт программ МПН-2015 и КОУЖ (периодичность наблюдения - 1 раз в 2 года; объем выборки - 60 тыс. домашних хозяйств) можно отметить наличие вопросов об образовании и здоровье населения. В КОУЖ блок вопросов об образовании, повторяя часть вопросов микропереписи (наивысший достигнутый уровень образования, посещение дошкольного учреждения, обучение в настоящий момент в образовательной организации), существенно шире - для каждого уровня образования предлагаются свои дополнительные вопросы. Помимо этого, изучаются образовательные планы, вовлеченность в дополнительное образование. То же можно и сказать о блоке вопросов о здоровье населения: повторяя часть вопросов микропереписи (наличие хронических заболеваний, потребность в помощи, наличие инвалидности и установленная ее группа), блок вопросов о здоровье несколько шире. Принципиальное отличие - наличие вопросов, позволяющих оценить состояние здоровья населения по самооценке опрашиваемого, распространенность курения и употребления алкогольных напитков, частоте употребления и ее структуре.

Вопросы о состоянии здоровья населения объединяют МПН-2015, «Выборочное наблюдение поведенческих факторов, влияющих на состояние здоровья населения» (периодичность проведения - 1 раз в пять лет; объем выборки - 15 тыс. домашних хозяйств) и «Выборочное наблюдение рациона питания населения» (периодичность проведения - 1 раз в пять лет; объем выборки - 45 тыс. домашних хозяйств). Однако вопросы микропереписи о здоровье и перечисленных обследований практически не повторяются. Интересно, что во всех трех выборочных обследованиях поставлен один и тот же вопрос, позволяющий оценить состояние здоровья населения по самоопределению опрашиваемого, и не задается вопроса о типе и степени функциональных ограничений организма, что могло бы показать более разнообразную картину состояния здоровья и инвалидизации населения.

Традиционные вопросы микропереписей о рождаемости и репродуктивных планах, суженные до двух в МПН-2015, находят свое продолжение в «Выборочном наблюдении репродуктивных планов населения» (периодичность проведения - 1 раз в пять лет; объем выборки - 15 тыс. домашних хозяйств). Из семи блоков индивидуального вопросника блок вопросов о рождаемости самый обширный («Рождение детей» и «Мотивы рождения детей»), он включает 33 вопроса. Вопросы призваны оценить не только уровень рождаемости, в том числе и по очередности рождения детей, но и осветить более широкий круг связанных тем: распространенность и методы контрацепции; распространенность абортов; репродуктивные планы, в том числе ближайшие, и желания; откладывание рождения детей и его причины; использование отпуска по уходу за ребенком; 
распространенность использования вспомогательных репродуктивных технологий; факторы и мотивы рождения детей. Помимо этого, вопрос о семейном положении (вопросник для домохозяйств), так же как и в КОУЖ, в отличие от микропереписи позволяет выделить пары разошедшиеся, но ранее состоящие в зарегистрированном браке и не разведенные официально. Индивидуальный вопросник содержит расширенный блок вопросов о брачности, позволяющий оценить брачное поведение. Предусмотрены вопросы о дате начала первого брака, его длительности, начале нынешнего брака, мнениях и факторах регистрации брака. Однако стоит отметить, что результаты данного обследования репрезентативны только на уровне страны в целом, ее городской и сельской местности, отдельных социально-демографических групп населения и семей, поэтому региональную вариативность репродуктивного и брачного поведения на его основе оценить невозможно.

Как и в МПН-2015, в выборочных обследованиях поставлен вопрос о составе домохозяйства, но он присутствует только в тех обследованиях, итоги которых репрезентативны не только на уровне страны в целом, но и на уровне ее регионов в связи с большим объем выборки: КОУЖ, выборочные наблюдения рациона питания, доходов населения и участия в социальных программах. Однако предложенные варианты отношений родства/свойства к ответственному лицу в выборочных обследованиях не полностью совпадают с перечнем, предложенным в МПН-2015.

Среди уникальных черт микропереписей, в том числе 2015 г. можно выделить наличие ряда традиционных для всеобщих переписей населения вопросов: о языке, о национальной принадлежности, гражданстве (МПН-2015), миграции населения, которые отсутствуют в других выборочных обследованиях.

\section{БУДУЩЕЕ: МИКРОПЕРЕПИСИ И ВСЕОБЩИЕ ПЕРЕПИСИ НАСЕЛЕНИЯ}

Будущее микропереписей населения в России, с одной стороны, стало более определено в связи с недавним принятием поправок в закон «О всероссийской переписи населения» ${ }^{9}$, которые фиксируют необходимость проведения микропереписи населения, ее срок и объем выборочной совокупности (п. 4 ст. 3).

С другой стороны, международный опыт проведения микропереписей населения показывает, что их практика не столь широка. Информацию о проведении микропереписи населения в последнее десятилетие удалось найти лишь в небольшом числе из четырех десятков рассмотренных стран (Венгрии, Гонконге, Латвии, Австрии, Германии). Информационное освещение микропереписей населения заметно уступает всеобщим переписям. Кроме того, под микропереписью в каждой стране могу пониматься весьма разные по своим организационно-методологическим характеристикам выборочные обследования. Поэтому, возможно, их число немного больше.

В Венгрии ${ }^{10}$ и Гонконге ${ }^{11}$ микроперепись населения проводится раз в пять лет между двумя всеобщими переписями населения, программа призвана дать, в первую очередь,

\footnotetext{
${ }^{9}$ Федеральный закон от 25.01.2002 №8-Ф3 (ред. от 28.03.2017) «О Всероссийской переписи населения».

${ }^{10}$ URL: http://www.ksh.hu/mikrocenzus2016/?lang=en (дата обращения: 26.06.2018).

"IURL:https://www.statistics.gov.hk/pub/B11200992016XXXXB0100.pdf (дата обращения: 26.06.2018 ).

WWW.DEMREVIEW.HSE.RU
} 
обновленную информацию по переменным из всеобщих переписей, во вторую -по переменным, отсутствующим во всеобщих переписях (индивидуальный вопросник в Венгрии содержит 39 вопросов, в Гонконге - 45). Традиционными для микропереписи Венгрии являются дополнительные выборочные обследования, в 2016 г. их темами были: социальная стратификация, профессиональный статус, субъективное благополучие, функциональные ограничения в связи с проблемами в здоровье, международная миграция.

Объем выборки микропереписи населения в обеих странах большой. В Гонконге 10\% всех кварталов с опросом всех домохозяйств, попавших в отобранный квартал, в Венгрии объем выборки был увеличен до $10 \%$ домохозяйств по сравнению с традиционными 2\%. Поэтому результаты обследований репрезентативны для достаточно низкого территориального уровня. Распределение выборок в обеих странах было диспропорциональным и варьировалось от территории к территории с целью получить структурные характеристики, репрезентативные для малых территорий. Например, в Венгрии объем выборки изменялся от региона к региону в пределах от 7,9 до 15,1\%.

Если в Венгрии или Гонконге микроперепись населения в большей степени похожа на российскую (хотя в МПН-2015 существенно меньше и объем выборки, и число вопросов в программе), то в Австрии и Германии это иной тип выборочного обследования.

Австрийская микроперепись населения проводится с 1967 г. Это ежеквартальное двухступенчатое стратифицированное выборочное обследование частных домохозяйств с объемом выборки 0,9\% всех адресов (31 тыс. зданий), варьирующейся в зависимости от численности населения той или иной земли. Отобранные адреса остаются в ней в течение двух лет, $1 / 8$ адресов заменяется ежеквартально. Программа микропереписи состоит из двух частей: базовой, не меняющейся и обязательной для заполнения части, и ежеквартально меняющейся дополнительной программы. На вопросы дополнительной программы отвечать не обязательно, она призвана дать информацию на актуальные темы, например, осветить условия жизни пожилых людей, лиц с ограниченными возможностями, условия труда, положение на рынке труда определенных групп населения [Wiedenhofer 2000]. Обследование рабочей силы (LFS) также встроено в расширенную часть микропереписи.

Микроперепись населения Германии, проводимая с 1957 г., напоминает австрийскую. Это ежегодное одноступенчатое стратифицированное кластерное выборочное обследование частных и коллективных домохозяйств с объемом выборки 1\% населения, имеющего право на проживание в Германии. Программа микропереписи также состоит из двух блоков:

1) базовой, ежегодной, не изменяющей от раунда к раунду, с числом вопросов более 200 , в рамках которой опрашивается $1 \%$ населения;

2) расширенной, с числом вопросов также более 200, в рамках которой с 2005 г. опрашивается $0,1 \%$ населения.

Тематика расширенной программы варьируется. В разные годы приоритетными темами были: участие разных групп населения на рынке труда (мигрантов, лиц с ограниченными возможностями на рынке труда, молодых людей), несчастные случаи на 
работе и профессиональные заболевания, процесс перехода на пенсию, работа и семейная жизнь. С 2005 г. вопросы обследования рабочей силы (LFS) также включены специальным модулем в программу микропереписи (с объемом выборки 1\% с 2012 г.) ${ }^{12}$.

Неширокое, на наш взгляд, распространение практики микропереписей населения может объясняться несколькими тенденциями последних лет.

Во-первых, этот вид статистического наблюдения нельзя рассматривать в отрыве от изменения методологии всеобщих переписей населения. Сейчас все больше распространяются альтернативные методы переписей населения (таблица 7), и основное внимание национальных статистических служб уделено разработке и апробации новой методологии, а также оценке качества полученных на ее основе данных. Так, в раунде переписей 2010 г. 21 из 68 рассмотренных стран провела перепись альтернативными методами (30\% всех обследованных стран), в раунде 2000 г. - 10 из 69 (14\%).

\section{Таблица 7. Распределение стран по методам переписи между раундами переписей} 2000 и 2010 г. среди всех обследованных стран

\begin{tabular}{|c|c|c|c|c|}
\hline & \multicolumn{2}{|c|}{ Раунд 2000} & \multicolumn{2}{|c|}{ Раунд 2010} \\
\hline & $\begin{array}{l}\text { число } \\
\text { стран }\end{array}$ & $\%$ & $\begin{array}{l}\text { число } \\
\text { стран }\end{array}$ & $\%$ \\
\hline Традиционная & 51 & 74 & 41 & 60 \\
\hline $\begin{array}{l}\text { в т.ч. комбинированный подход на основе традиционной } \\
\text { переписи }\end{array}$ & 0 & - & 1 & - \\
\hline "Скользящая" перепись & 0 & - & 1 & 1 \\
\hline в т.ч. комбинированный подход на основе "скользящей" переписи & 0 & - & 0 & - \\
\hline Перепись на основе регистров & 10 & 14 & 20 & 29 \\
\hline $\begin{array}{l}\text { в т.ч. комбинированный подход на основе регистров: } \\
\text { из них: }\end{array}$ & 8 & - & 14 & - \\
\hline регистр и существующее выборочное обследование & 1 & - & 3 & - \\
\hline регистр и специальное выборочное обследование & 1 & - & 7 & - \\
\hline регистр и сплошной опрос & 6 & - & 4 & - \\
\hline Еще не проведена & 7 & 10 & 6 & 9 \\
\hline Не известно & 1 & 1 & 0 & 0 \\
\hline Всего & 69 & $99^{*}$ & 68 & $99 *$ \\
\hline
\end{tabular}

Примечание: *сумма меньше 100\% из-за округления

Источник: [Пьянкова 2015: 88].

В раунде 2020 г. доля стран, перешедших на альтернативные методы, вырастет за счет Южной Кореи, Италии, Македонии, а возможно, и других стран. В этих странах уже реализован переход на альтернативные методы переписи (Южная Корея) или он в процессе реализации (Италия, Македония). Помимо этого, расширится круг стран, проводящих перепись полностью на основе регистров, за счет как отказа от традиционной переписи (Южная Корея, Македония), так и отказа от такого временного, но необходимого на определенном этапе, варианта проведения переписи, как комбинация регистров и сплошного опроса населения (Эстония, Латвия и, может быть, Литва).

Однако изменение методологии всеобщей переписи населения не означает отказа от микропеписи, меняются ее место в системе статистического наблюдения и цель. Возможно,

${ }^{12}$ URL: https://www.gesis.org/en/missy/metadata/MZ/ (дата обращения: 26.06.2018). 
в процессе перехода к новым методам проведения сплошных переписей роль микропереписи усиливается, приобретая контрольные функции. Так, в Латвии в 2011 г. всеобщая перепись населения была проведена комбинированным способом с использованием регистров и сплошного опроса. Целью микропереписи населения 2015 г. была оценка качества полученной информации с использованием новой методологии микропереписи и данных регистров, а также получение данных по структуре образования, в том числе полученного за рубежом [Zukula 2016]. Предстоящую перепись населения в Латвии планируют провести полностью на основе регистров.

В Германии на территории ФРГ последняя традиционная перепись населения была проведена в 1987 г., на территории ГДР - в 1981 г. Причиной стали волнения в обществе, рассматривающем перепись населения как вторжение в частную жизнь. В 1991 г. было принято решение о замене традиционной переписи ежегодными микропереписями населения с выборкой 1\%, базой для которой послужили всеобщие переписи населения 1987 и 1981 г. Основной целью микропереписей было получение информации о структурных характеристиках населения, поведении на рынке труда и жилищных условиях в отсутствии всеобщей переписи населения [Edin, Rendtel 2007]. Со временем оценки численности населения становились все менее точными из-за переоценки численности некоторых групп населения. В частности, статистикой международной миграции недоучитывались выбытия за пределы страны в результате несвоевременного снятия с учета в муниципальных регистрах [Kibele et al. 2008: 189]. Всеобщая перепись состоялась в 2011 г. с использованием муниципальных регистров населения. Однако статистическое агентство Германии не отказалось от микропереписи населения [Bujard, Scheller 2017: 65].

Во-вторых, из таблицы 7 видно, что переход на альтернативные методы переписи сопровождается широким распространением выборочных методов в рамках всеобщих переписей, преимущественно в комбинации с регистрами. Целями выборочной части всеобщих регистровых переписей могут быть как проверка полноты и качества существующих регистров, так и получение переменных, отсутствующих в регистрах, и создание новых регистров. Выборочная часть используется и в странах, где проводится традиционная всеобщая перепись: Канаде, Бразилии, США, Гонконге, Венгрии и др.

В этой связи необходимо упомянуть «Обследование Американских Общин» («ОАО»), пришедшее на замену длинному переписному листу, с целью, с одной стороны, снизить затраты на всеобщую перепись, с другой стороны, повысить охват обследуемого населения по короткому переписному листу, а данные по широкой программе получать чаще, чем раз в 10 лет. «ОАО» двухфазовое двухступенчатое обязательное выборочное обследование, характеризуемое достаточно высоким процентом откликов - 97\% в среднем за период 2005-2014 годов. Несмотря на то, что программа «ОАО», практически, повторяет программу длинного переписного листа, принципиальная разница состоит в методологии. «ОАО» - это ежемесячное скользящее выборочное обследование и как следствие собираемые данные приурочены не к фиксируемому моменту времени, а к периоду времени, в течение которого происходил сбор данных. Помимо этого выборка «ОАО» существенно меньше выборки длинного переписного листа (в рамках переписи 2000 для ответов на длинный переписной лист выбиралось 1 из 6 домохозяйств, то в рамках «ОАО» 1 из 50). Основой выборки является мастер файл адресов, актуальность которого 
поддерживается Бюро переписей на постоянной основе. В «ОАО» обследуются два типа домохозяйств: частные домохозяйства и для групповых домохозяйств (студенты, рабочих, проживающие в общежитии, лица, проживающие в домах престарелых и коррекционных, лечебных учреждениях, военные, проживающие в бараках, бездомные, пребывающие в местах их группового пребывания и т.д.).

В настоящее время осуществляется три вида оценок по переменным: ежегодные оценки для территорий с численностью населения более 65 тыс. человек (с 2005 года), дополнительные ежегодные оценки для территорий с численностью населения более 20 тыс. человек по определенным группам населения (с 2014 года) и пятилетние оценки для всех территориальных единиц (с 2010 года). Ранее выполнялись еще оценки за трехлетний период, но с 2014 года публикация этих данных прекращена.

Первые два вида оценок базируются на 12 ежемесячных независимых выборках, сбор данных в рамках каждой из которых длится три месяца. В течение первого месяца происходит рассылка вопросников по почте и сбор данных по почте, а с 2012 года и по Интернету; в течение второго месяца среди не ответивших на первом этапе, в случае наличия телефонного номера, проводится телефонное интервью; только на третьем этапе переписчик опрашивает оставшиеся домохозяйства в рамках личного интервью. Ежегодный объем выборки в период 2005-2010 годов составлял 3 млн. адресов, затем он был увеличен до 3,5 млн. адресов. Третий вид оценок, для единиц самого низкого территориального уровня (уровень сопоставим с теми территориальными единицами, на которые был ориентирован длинный переписной лист переписи 2000 года), базируется на 60 ежемесячных независимых выборках, соответственно объем выборочной совокупности в период 2005-2009 годов составлял 15 млн. адресов, затем 18 млн. адресов. Первые пятилетние оценки были опубликованы Бюро переписей в 2010 году, которые были получены путем объединения данных, собранных в период с 1 января 2005 года по 31 декабря 2009 года.

Вследствие меньшего объема выборки «ОАО», особую значимость приобретает степень точности оценок. Поэтому помимо самих оценок Бюро переписей публикует еще и оценки погрешности, вызванные ошибками выборки, что позволяет пользователю с уровнем значимости 90\% оценивать степень вариативности оценок по той или иной переменной.

В-третьих, в ряде стран (Австралия, Канада, Ирландия, Новая Зеландия, Япония, Южная Корея) всеобщая перепись населения проводится раз в пять лет, дополняясь обширной системой выборочных обследований, поэтому необходимость в микропереписи населения невелика. В некоторых из этих стран переписной лист весьма длинный (Австралия - 54 вопроса в индивидуальном листе, Ирландия - 34, Новая Зеландия - 50). В Канаде всеобщая перепись 2016 г. представляет собой комбинацию короткого листа для всего населения и длинного переписного листа для 25\% населения.

B-четвертых, происходит интеграция уже полученных данных всеобщих переписей и предоставление их во всеобщее пользование - создание лонгитюдных данных, 
объединяющих выборки разных всеобщих переписей населения (Австралия ${ }^{13}$ ), что позволяет проследить фундаментальные демографические тенденции. В Германии и Австрии возможно создание лонгитюдных данных на основе микропереписей, однако существуют определенные проблемы при их использовании. В Германии это связано с тем, что выборка микропереписи территориальная с отбором жилых помещений без отслеживания тех, кто переехал на новое место жительства, что может вести к систематическому смещению ряда показателей, особенно связанных с участием в рынке труда [Basic, Rendtel 2007: 2].

\section{ЗАКЛЮЧЕНИЕ}

Первая микроперепись населения 1985 г. в какой-то мере была революционным событием для своего времени, дав новый импульс для фундаментальных исследований глубинных демографических процессов в последующее десятилетие. Микроперепись 1994 г. еще больше расширила эмпирическую базу для демографических исследований.

Данным микропереписи 2015 г. присущи определенные недостатки. Из-за небольшого объема выборки и ее значительной вариативности по регионам систематически занижены регионы с высокой численностью населения и городские агломерации. В результате пострадала репрезентативность данных по стране в целом, наблюдается смещенность социально-демографических и географических характеристик населения. Насколько в этой ситуации будут востребованы исследователями результаты МПН-2015 покажет время. Однако понятно, что в условиях малой выборки достичь репрезентативности как по стране в целом, так и по территориальным единицам более низкого уровня невозможно.

Обобщающих международных рекомендаций относительно проведения микропереписей населения нет. Цели и организационно-методологические характеристики микропереписей, отвечая национальным потребностям, существенно различаются по странам, но они всегда взаимоувязаны с целями и организационно-методологическими особенностями всеобщих переписей населения. В странах с развитой системой выборочных обследований микропереписи либо встречаются редко, либо, преодолев свое некое промежуточное положение между всеобщими переписями и другими выборочными обследованиями, проводятся с большей регулярностью (чаще) и являются интеграционной базой для остальных выборочных обследований.

\section{ЛИТЕРАТУРА}

Андреев Е.М. (2012). О точности результатов Российских переписей населения и степени доверия к разным источникам информации о населении // Вопросы статистики. 11: 21 35. 
Андреев Е.М., Г.А. Бондарская (2000). Можно ли использовать данные об ожидаемом числе детей в прогнозе численности населения // Вопросы статистики. 11: 56-62.

Андреев Е.М., Г.А. Бондарская, Т.Л. Харькова (1998). Падение рождаемости в России: гипотезы и факты // Вопросы статистики. 10: 82-93.

Андреев Е.М., М.В. Рахманинова (1999). Внутренняя миграция в России: прошлое и настоящее // Вопросы статистики. 5: 53-63.

Андреев Е.М., С.В. Захаров (2017). Микроперепись-2015 ставит под сомнение результативность мер по стимулированию рождаемости // Демоскоп Weekly. 711-712. URL: http://www.demoscope.ru/weekly/2017/0711/tema02.php (дата обращения: 15.05.2018).

Андреев Е.М., Т.Л. Харькова (2013). Сравнительный анализ данных из разных источников о числе рожденных детей // Вопросы статистики. 5: 38-46.

База микроданных федерального статистического наблюдения «Социальнодемографическое обследование (микроперепись населения) 2015 года» (2015). Росстат. URL: http://vpnmicrodata.gks.ru/webapi/jsf/tableView/tableView.xhtml (дата обращения: 15.05.2018).

Белов И. (1986). О выборочном социально-демографическом обследовании населения 1985 г. // Вестник статистики. 9: 40-45.

Вишневский А.Г., С.В. Захаров (2010). Что знает и чего не знает российская демографическая статистика // Вопросы статистики. 2: 7-17.

Волков А.Г. (1984). Первая микроперепись населения СССР // Здравоохранение Российской Федерации. 10: 3-6.

Волков А.Г. (2014а). Методология и организация микропереписи в России в 1994 г. // Избранные демографические труды. М.: Изд. дом ВШЭ: 180-198.

Волков А.Г. (2014б). Новые особенности формирования семьи и ее состав: пример России // Избранные демографические труды. М.: Изд. дом ВШЭ: 432-447.

Волков А.Г. (2014в). Этнически смешанные семьи в СССР: динамика и состав // Избранные демографические труды. М.: Изд. дом ВШЭ: 405-431.

Волков А.Г., Е.Л. Сороко (1999). Типология семей и домохозяйств в России: развитие и анализ (по данным микропереписи 1994 года) // Вопросы статистики. 5: 40-52.

Дарский Л.Е. (2005). Ожидаемое число детей у женщин разных национальностей и перспективы рождаемости в населении бывшего CCCP // Демоскоп Weekly. 191-192. URL: http://www.demoscope.ru/weekly/2005/0191/nauka02.php (дата обращения: 30.05.2018).

Дарский Л.Е., И.П. Ильина (1990а). Нормализация брачности в СССР // Демографические процессы в СССР / Под ред. А.Г. Волкова. М.: Наука: 6-27.

Дарский Л.Е., И.П. Ильина (1990б). Таблицы брачности основных национальностей союзных республик СССР (По данным выборочного обследования 1985 г.) // Экономика. Демографическая статистика: Исследования и проблемы. М.: Наука: 206210.

Дарский Л.Е., И.П. Ильина (2000). Брачность в России. Анализ таблиц брачности / Под ред. А.Г. Волкова. М.: Информатика. 144 с. 
Доклад Росстата (2016). Об основных итогах федерального статистического наблюдения «Социально-демографическое обследование (микроперепись населения) 2015 года». URL: http://www.gks.ru/free_doc/new_site/population/demo/micro-perepis/finish/doklad.pdf (дата обращения: 12.05.2018).

Захаров С.В. (2006). Возраст вступления в первый брак /Демографическая модернизация России, 1900-2000 / Под ред. А.Г. Вишневского. М.: Новое издательство: 107-120.

История переписей населения в России (2013). М.: Голден Би. 414 с.

Исупов А.А. (1992). Программа социально-демографического обследования 1994 года // Вестник статистки. 9: 25-28.

Итоги выборочного социально-демографического обследования населения 1985 (1986) // Вестник статистики. 7: 67-79; 8: 72-80; 9: 75-78.

Кузнецов Л.Р. (1990). Взаимосвязь миграции и брачности // Демографические процессы в СССР. М.: Наука: 58-77.

Кузнецов Л.Р. (1992а). Особенности матримониального поведения мигрантов // Миграция. Демография и социология. Вып. 2. М.: 163- 180.

Кузнецов Л.Р. (1992б). Статистическое изучение взаимосвязи демографических процессов и миграции. Автореферат диссертации, Москва: Научно-исследовательский институт статистики. 27 с.

Методические пояснения к социально-демографическому обследованию (микроперепись населения) 2015 года (2015). URL: http://www.gks.ru/free_doc/new_site/population/demo/micro-perepis/finish/microperepis.html (дата обращения: 15.05.2018).

Мкртчян Н.В. (2012). Проблемы учета населения отдельных возрастных групп в ходе переписи населения 2010 г.: причины отклонений полученных данных от ожидаемых // Демографические аспекты социально-экономического развития / Под ред. М.Б. Денисенко. Вып. 22. М.: МАКС Пресс: 197-214.

Никитина С.Ю. (2013). Об организационных и методологических вопросах выборочного федерального статистического наблюдения «Микроперепись 2015 г.». Презентация доклада на расширенном заседании коллегии Росстата 12.02.2013. URL: http://www.gks.ru/free_doc/new_site/rosstat/smi/smi-1302.html (дата обращения: 21.11.2017).

Никитина С.Ю. (2015) Об организационных и методологических вопросах выборочного федерального статистического наблюдения «Микроперепись населения 2015 г.» // Вопросы статистики. 3: 35-37.

Основные итоги микропереписи населения 1994 г. в 8 томах (1995). М.: Государственный комитет Российской Федерации по статистике.

Пьянкова А.И. (2015). Традиционный и альтернативные методы проведения переписей населения: дисс. к-та соц. наук. М.: Высшая школа экономики.

Рамонов А.В., А.И. Пьянкова (2014). Изучение здоровья: потенциал переписей населения // Демографическое обозрение. 1(2): 140-155.

Сводные результаты оценки репрезентативности блоков таблиц с итогами микропереписи $\begin{array}{llll}\text { населения } 2015 & \text { года. }\end{array}$ http://www.gks.ru/free_doc/new_site/population/demo/micro-perepis/finish/microperepis.html (дата обращения: 15.05.2018). 
Таблицы с итогами федерального статистического наблюдения «Социальнодемографическое обследование (микроперепись населения) 2015 года» (2015). URL: http://www.gks.ru/free_doc/new_site/population/demo/micro-perepis/finish/microperepis.html (дата обращения: 15.05.2018).

Чернышева Т.М. (1990). Методология формирования территориальной выборки в СССР // Кооперация стран - членов СЭВ в статистике. Вып. 6. М.: Изд-во СЭВ: 12-23.

Численность населения (2015). Статистический бюллетень «Численность населения Российской Федерации по полу и возрасту на 1 января 2015 года». M: Росстат. URL: http://www.gks.ru/bgd/regl/B15_111/Main.htm (дата обращения: 15.05.2018).

Численность населения (2016). Статистический бюллетень «Численность населения Российской Федерации по полу и возрасту на 1 января 2016 года». М.: Росстат. URL: http://www.gks.ru/bgd/regl/B16_111/Main.htm (дата обращения: 15.05.2018).

Численность населения (2017). Статистический бюллетень «Численность населения Российской Федерации по полу и возрасту 1 января 2017 года». М.: Росстат. URL: http://www.gks.ru/bgd/regl/b17_111/Main.htm (дата обращения: 15.05.2018).

Andreev E.M. (2001). Jews in Russia's Households (Based on the 1994 Microcensus) // Papers in Jewish Demography 1997 / S. Della Pergola, J. Even, eds. Jerusalem: The Hebrew University of Jerusalem: 141-159.

Zukula B. (2016). Methodology of estimating the annual number of usual resident population in Latvia // Paper presented at the Conference of European Statisticians (Switzerland, Geneva, 18-20 May 2016). URL: http://www.unece.org/fileadmin/DAM/stats/documents/ece/ces/ge.10/2016/mtg2_WS/23_Lat via_BZukula_ENG.pdf (дата обращения: 15.05.2018).

Edin B., U. Rendtel (2007). Assessing the bias due to non-coverage of residential movers in the German Microcensus Panel: an evaluation using data from the Socio-Economic Panel // Advances in Statistical Analysis. 91(3): 311-334.

Barkalov N.B. (1997). Expected fertility as it appears from the 1994 microcensus a parityprogression dimension] // Population: the current state and prospects for the development of scientific knowledge. Collection of reports of the first Valantey conference. Moscow: 118-137.

Barkalov N.B. (1999). The fertility decline in Russia, 1989-1996: a view with period parityprogression rations // Genus. 55 (3-4): 11-60.

Barkalov N.B. (2005). Changes in the quantum of Russian fertility during the 1980s and early 1990s // Population and Development Review. 31(3): 545-556.

Bujard M., M. Scheller (2017). Impact of Regional Factors on Cohort Fertility: New Estimations at the District Level in Germany // Comparative Population Studies. 42: 55-88.

Bondarskaya G. (1994). Ethnic-Territorial Differences in Marital Fertility: A 1985 Survey / Demographic Trends and Patterns in the Soviet Union Before 199 / W. Lutz, S. Scherbov, A. Volkov, eds. London and New York: Routledge: 71-87.

Darsky L.E. (1994). Quantum and timing of births in the USSR / Demographic Trends and Patterns in the Soviet Union Before 1991 / W. Lutz, S. Scherbov, A.G. Volkov, eds. London and New York: Routledge: 57-69.

Darsky L.E., S. Scherbov (1990). Parity-progression fertility tables for the nationalities of the USSR. IIASA Working Papers, Laxenburg. WP-90-53. 
Kharkova T.L., E.M. Andreev (2000). Did the Economic Crisis Cause the Fertility Decline in Russia: Evidence from the 1994 Microcensus // European Journal of Population. 16(3): 211233.

Kibele E., R. Scholz, V.M. Shkolnikov (2008). Low migrant mortality in Germany for men aged 65 and older: Fact or artifact // European Journal of Epidemiology. 23(6): 389-393.

Mills M. (2000). The transformation of Partnerships. Canada, the Netherlands, and the Russian Federation in the Age of Modernity. Amsterdam: Thela Thesis. 278 p.

Mills M. (2004). Stability and change: the structuration of partnership histories in Canada, the Netherlands, and the Russian Federation // European Journal of Population. 20: 141-175.

Scherbov S., van Vianen H. (1999). Marital and Fertility Careers of Russian Women Born between 1910 and 1934 // Population and Development Review. 25 (1): 129-143.

Scherbov S., van Vianen H. (2001). Marriage and Fertility in Russia of Women Born between 1900 and 1960: A Cohort Analysis // European Journal of Population. 17(3): 281-294.

Scherbov S., van Vianen H. (2002). Period Fertility in Russia since 1930: an application of the Coale-Trussell fertility model // Demographic Research. 6: 455-470.

Scherbov S., van Vianen H. (2004). Marriage in Russia: a reconstruction // Demographic Research. 10: $27-60$.

Soroko E.L. (2001). Jewish Households in Russia according to the 1994 Microcensus // Papers in Jewish Demography 1997 / S. Della Pergola, J. Even, eds. Jerusalem: The Hebrew University of Jerusalem: 161-179.

Tolts M. (1996). The Jewish Population of Russia, 1989-1995 // Jews in Eastern Europe. 3 (31): 5-19.

Tolts M. (1997). The Interrelationship between Emigration and the Socio-Demographic Profile of Russian Jewry / N. Lewin-Epstein, Y. Ro'i, P. Ritterband, eds. Russian Jews on Three Continents. London: Frank Cass: 147-176.

Tolts M. (1998). Recent Jewish Emigration and Population Decline in Russia // Jews in Eastern Europe. 1 (35): 5-24.

Tolts M. (1999). Yiddish in the Former Soviet Union Since 1989: A Statistical-Demographic Analysis // G. Estraikh, M. Krutikov, eds. Yiddish in the Contemporary World. Oxford: European Humanities Research Centre, University of Oxford. 133-146.

Volkov A.G. (1999a). New features of family formation and composition: case of Russia // Revue Baltique. Vilnius. 13: 82-96.

Volkov A.G. (1999b). Methodology and Organization of the 1994 Microcensus in Russia. Population Research Centre, University of Groningen. Working Paper 99-5.

Wiedenhofer B. (2000). Assistance for/ by women and men aged 60 years or more. Paper presented at the Conference of European Statisticians (Italy, Orvieto, 11-13 October 2000). URL: http://www.unece.org/fileadmin/DAM/stats/documents/2000/10/gender/12.e.pdf (дата обращения: 15.05.2018). 


\section{ПРИЛОЖЕНИЕ}

\section{Программа микропереписи населения 1994 года (утверждена постановлением Госкомстата России от 22.02.93 № 23)}

\begin{tabular}{|c|c|}
\hline \multicolumn{2}{|r|}{$\begin{array}{l}\text { Жилищные условия домохозяйства и сведения о наличии приусадебного, садового, дачного } \\
\text { участка, огорода }\end{array}$} \\
\hline 1 & $\begin{array}{l}\text { Тип жилого помещения: индивидуальный дом, часть индивидуального дома, отдельная квартира, } \\
\text { общая квартира, общежитие, другое жилое помещение, снимает жилое помещение. }\end{array}$ \\
\hline 2 & Принадлежность жилого помещения: частный жилищный фонд, государственный жилищный фонд. \\
\hline 3 & Число комнат (часть комнаты). \\
\hline 4 & Размер площади (кв. м): общей, жилой. \\
\hline 5 & $\begin{array}{l}\text { Наличие приусадебного участка и его размер (соток): приусадебный участок; садовый или дачный } \\
\text { участок; огород; не имеет. }\end{array}$ \\
\hline \multicolumn{2}{|r|}{ Заполняется для постоянно проживающих членов домохозяйства } \\
\hline & ФИО \\
\hline 1 & $\begin{array}{l}\text { Отношение к лицу, записанному первым: лицо, записанное первым; муж, жена; сын, дочь; отец, } \\
\text { мать; брат, сестра; другой родственник; не родственник. }\end{array}$ \\
\hline 2 & Укажите номер, под котором записаны мать и отец данного лица. \\
\hline 3 & Пол: мужской, женский. \\
\hline 4 & Дата рождения: число, месяц, год рождения; число исполнившихся лет. \\
\hline 5 & $\begin{array}{l}\text { Место рождения: государство, республика, край, область, округ; городское поселение, сельская } \\
\text { местность. }\end{array}$ \\
\hline 6 & $\begin{array}{l}\text { В данном населенном пункте проживает непрерывно (не считая переезда в пределах города или из } \\
\text { села в село в пределах одного района): с рождения; не с рождения. }\end{array}$ \\
\hline 7 & Если не с рождения, то с какого года: год. \\
\hline 8 & $\begin{array}{l}\text { Место предыдущего постоянного жительства: государство, республика, край, область, округ; } \\
\text { городское поселение, сельская местность. }\end{array}$ \\
\hline 9 & $\begin{array}{l}\text { Причины смены места постоянного жительства: в связи с переменой места работы; из-за } \\
\text { невозможности устроиться на работу; не было возможности заниматься самостоятельно сельским } \\
\text { хозяйством; не было возможности заниматься предпринимательством или индивидуальной } \\
\text { трудовой деятельностью; из-за обострения межнациональных отношений; в связи с обязательным } \\
\text { знанием языка коренной национальности; из-за обострения криминогенной обстановки; из-за } \\
\text { неустроенности быта; из-за смены климата в связи с состоянием здоровья; не удовлетворяли } \\
\text { экологические условия; в связи с аварией на Чернобыльской АЭС; нежелание жить в селе (городе); } \\
\text { по семейным обстоятельствам; иная причина (указать какая). }\end{array}$ \\
\hline 10 & К какой национальности, народности, этнической группе себя относите. \\
\hline 11 & Родной язык. \\
\hline 12 & Другой язык, которым свободно владеет. \\
\hline 13 & $\begin{array}{l}\text { Язык, которым преимущественно пользуется: дома; учебном заведении; школьном учреждении; на } \\
\text { работе. }\end{array}$ \\
\hline \multicolumn{2}{|r|}{ Заполняется для лиц в возрасте 6 лет и старше } \\
\hline 14 & $\begin{array}{l}\text { Образование: высшее; незаконченное высшее; среднее специальное; среднее общее; неполное } \\
\text { среднее; начальное; не имеет начального образования; неграмотные(ая). }\end{array}$ \\
\hline 15 & $\begin{array}{l}\text { Сколько курсов (классов) закончили в каждом перечисленном типе учебного заведения: в вузе } \\
\text { (величина); в среднем специальном учебном заведении (величина); в общеобразовательной школе } \\
\text { (величина); в ПТУ (величина); не закончил ни одного курса (класса). }\end{array}$ \\
\hline 16 & $\begin{array}{l}\text { Тип законченного учебного заведения: вуз; среднее специальное учебное заведение; } \\
\text { общеобразовательная школа; ПТУ; никакого, но умеет читать и писать; никакого, но умеет только } \\
\text { читать; никакого, не умеет ни читать, ни писать. }\end{array}$ \\
\hline 17 & $\begin{array}{l}\text { Тип учебного заведения, в котором учитесь, и форма обучения: вуз; среднее специальное учебное } \\
\text { заведение; общеобразовательная школа; ПТУ; иная школа (курсы); не учусь; дневная форма } \\
\text { обучения; вечерняя (заочная) форма обучения. }\end{array}$ \\
\hline \multicolumn{2}{|r|}{ Заполняется для лиц в возрасте 15 лет и старше и всех до 15 лет состоящих в браке } \\
\hline 18 & $\begin{array}{l}\text { Состояние в браке: в зарегистрированном браке; в незарегистрированном браке; вдов(а); разведен(а); } \\
\text { разошелся(лась); никогда не состоял(а) в браке. }\end{array}$ \\
\hline 19 & Для состоящих в браке указать номер, под которым записан супруг (а). \\
\hline 20 & В каком по счету браке состоите или состояли. \\
\hline 21 & Іления в первый брак: месяц, год. \\
\hline
\end{tabular}


22 Время и причина прекращения первого брака: месяц, год; развелся(лась); разошелся(лась); овдовел(а).

23 Время вступления во второй брак: месяц, год.

Для женщин 15 лет и старше, а также моложе 15 лет, родивших детей

24 Общее число детей родившихся живыми (включая умерших)

25 Для каждого ребенка (с 1 по 10) указать: время рождения (месяц, год); если умер, время смерти (месяц, год); если проживает отдельно, то с какого года (год).

Заполняется для женщин в возрасте 15-44

26 Сколько детей собираетесь иметь, включая уже имеющихся.

27 Сколько детей хотели бы иметь.

Заполняется для всех лиц

28 Укажите все источники средств существования: заработная плата на предприятии, в организации, учреждении всех форм собственности, оплата труда в колхозе; доход от предпринимательской деятельности; доход от фермерского хозяйства; доход от работы у отдельных граждан; личное подсобное хозяйство; доход от собственности (дивиденды, проценты, доход от сдачи в аренду жилого помещения, автомобиля и др. собственности); стипендия; пенсия по возрасту или за выслугу лет; пенсия по инвалидности; пенсия по случаю потери кормильца; пособие по безработице; различные пособия (кроме пособия по безработице); другой вид государственного обеспечения; на иждивении отдельных лиц; иной источник.

29 Укажите общую сумму дохода за январь, включая все поступления: рублей.

Заполняется на лиц 15 лети старше в обследуемый период 7 - 13 февраля 1994 г.

30 В течение недели выполнял(а) ли какую-нибудь оплачиваемую работу, или имел занятие, приносящее доход: да; нет.

31 В течение этой недели отсутствовал(а) ли на работе временно (болезнь, отпуск, обучение и т.д.): да, нет.

32 В течение этой недели выполнял(а) ли какую-нибудь неоплачиваемую работу на ферме или на предприятии принадлежащем кому-либо из родственников: да, нет.

33 В течение недели занимался(лась) производством сельскохозяйственной продукции, ловлей рыбы, охотой или продавал добытое, произведенное: да, нет.

34 Основное место работы: воинская служба в Вооруженных Силах; на государственном предприятии, в организации, учреждении; на муниципальном предприятии; на арендном предприятии; на предприятии потребительского союза; в общественной организации или на предприятии, ей принадлежащем; на акционерном предприятии открытого типа; у отдельных граждан; самостоятельно обеспечивали себя работой; на частном индивидуальном, семейном предприятии; в фермерском хозяйстве; в производственном кооперативе; в колхозе; в другом коллективном сельскохозяйственном предприятии; в товариществе, акционерном предприятии закрытого типа; другое.

35 Работал(а) ли по найму: да, нет.

36 Вы являлись: работающим(ей) не по найму; работающим(ей) по найму; неоплачиваемым работником семейного предприятия.

37 Вы работал(а) с привлечением наемных работников: да, нет.

38 В течение месяца перед опросом искал(а) работу или пытался(лась) организовать собственное дело: искал(а) работу; принял(а) меры для открытия собственного дела; не искал(а), так как получил(а) работу, приступил(а) или приступлю в ближайшую неделю; нашел(а), ожидаю ответа; зарегистрирован в службе занятости в качестве ищущего работу; обучаюсь по направлению службы занятости; жду приглашения с последнего места работы в течение месяца; жду приглашения с последнего места работы более одного месяца; получил повестку о призыве на воинскую службу; отчаялся(лась) найти работу; нет необходимости или возможности работать; другое.

39 Как искали работу: обращались в службу занятости в государственную; в коммерческую; через печать (объявления); используя личные связи; через непосредственное обращение к администрации (работодателю); другие способы; способ поиска работы не указан.

40 Если бы Вы получили подходящую работу на обследуемой неделе смогли бы приступить к ней немедленно: да, нет.

41 Вы были зарегистрированы в качестве безработного: да, нет.

Для длительное время отсутствующих в домохозяйстве

\begin{tabular}{|l|l|}
\hline 42 & вопрос 1 \\
\hline 43 & вопрос 2 \\
\hline 44 & вопрос 3 \\
\hline 45 & вопрос 4 \\
\hline 46 & вопрос 10 \\
\hline
\end{tabular}


47 вопрос 18

48 вопрос 19

49 Причина отсутствия: выезд на работу в России; выезд за границу для работы; выезд на учебу; срочная служба в армии; содержание в местах заключение; иная причина; не указавшие причину; время, с которого отсутствует в домохозяйстве (месяц, год).

\section{Программа микропереписи населения 2015 года (утверждена приказом Росстата от 22.04.2014 г. №26 )}

\begin{tabular}{|c|c|}
\hline № & Формулировка вопроса и подсказы \\
\hline 1 & $\begin{array}{l}\text { Первому по порядку члену домохозяйства отметьте «записан первым». Остальным членам } \\
\text { домохозяйства отметьте, кем он (она) приходится тому, кто записан первым: записан первым; жена, } \\
\text { муж (зарегистрированные и незарегистрированные); дочь, сын; мать, отец; сестра, брат; свекровь, } \\
\text { свекор, теща, тесть; невестка (сноха), зять; бабушка, дедушка; внучка, внук; другая степень родства, } \\
\text { свойства; не родственник (указать). Если мать (или отец) этого лица проживает с ним в одном } \\
\text { домохозяйстве, то проставьте порядковый номер из зоны Б, под которым записана мать (или отец) } \\
\text { опрашиваемого. }\end{array}$ \\
\hline 2 & Пол: мужской, женский. \\
\hline 3 & Дата рождения: число, месяц, год рождения; число исполнившихся лет. \\
\hline 4 & $\begin{array}{l}\text { Место рождения: республика, край, область, авт. область, авт. округ, г. Москва, г. Санкт-Петербург, } \\
\text { г. Севастополь для России или наименование иностранного государства. }\end{array}$ \\
\hline \multicolumn{2}{|r|}{ Для лиц в возрасте 16лет и более и состоящих в браке до 16 лет } \\
\hline 5 & $\begin{array}{l}\text { Ваше состояние в браке (супружеском союзе): состою в браке (супружеском союзе) } \\
\text { зарегистрированном; состою в браке (супружеском союзе) в незарегистрированном; разведен(а) } \\
\text { официально (развод зарегистрирован); разошелся(лась); вдовец, вдова; никогда не состоял(а) в браке } \\
\text { (супружеском союзе). }\end{array}$ \\
\hline 6 & Какими языками Вы владеете: указать язык (можно указать три); русским языком, жестовым языком. \\
\hline 7 & Какие из этих языков Вы используете в повседневной жизни: можно указать 4 варианта. \\
\hline 8 & Ваш родной язык: можно указать 1 вариант. \\
\hline 9 & $\begin{array}{l}\text { Ваше гражданство: РФ; для иностранных граждан указать государство; для граждан РФ указать } \\
\text { второе гражданство; без гражданства. }\end{array}$ \\
\hline 10 & $\begin{array}{l}\text { Как и когда Вы получили российское гражданство: по рождению или замене паспорта СССР; в } \\
\text { порядке регистрации гражданства РФ в 1992-2000 гг. (год, прежнее гражданство); в результате } \\
\text { приема в гражданство РФ (год, прежнее гражданство); в результате восстановления в гражданстве } \\
\text { РФ (год, прежнее гражданство). }\end{array}$ \\
\hline 11 & $\begin{array}{l}\text { Ваша национальная принадлежность (по самоопределению опрашиваемого); можно указать одну; } \\
\text { отказ от ответа. }\end{array}$ \\
\hline 12 & $\begin{array}{l}\text { С какого года Вы непрерывно проживаете в этом населенном пункте: с рождения; не с рождения } \\
\text { (указать год), если } 2010 \text { г., то месяц. }\end{array}$ \\
\hline 13 & Ваше предыдущее место жительства: наименование субъекта РФ или иностранного государства. \\
\hline 14 & $\begin{array}{l}\text { Где Вы проживали в октябре } 2010 \text { года: наименование субъекта РФ или иностранного государства; } \\
\text { в городском населенном пункте, в сельском населенном пункте. }\end{array}$ \\
\hline 15 & $\begin{array}{l}\text { Зарегистрированы ли Вы в помещении, в котором сейчас постоянно проживаете: да (указать вид } \\
\text { регистрации: по месту жительства, по месту пребывания); нет; если нет или по месту пребывания } \\
\text { указать: зарегистрирован в том же населенном пункте, в котором находится место жительства; } \\
\text { зарегистрирован в другом населенном пункте того же субъекта РФ; в другом субъекте РФ (указать } \\
\text { каком); нет постоянной регистрации на территории РФ. }\end{array}$ \\
\hline \multicolumn{2}{|r|}{ Заполняется для лиц в возрасте 6 лет и более } \\
\hline 16 & Учитесь ли Вы в образовательной организации: да; нет. \\
\hline 18 & $\begin{array}{l}\text { Ваше образование: дошкольное (для детей от 6-9 лет); начальное общее (начальное); основное общее } \\
\text { (неполное среднее); среднее общее (среднее полное общее); по программе подготовки } \\
\text { квалифицированных рабочих, служащих (начальное профессиональное); по программе подготовки } \\
\text { специалистов среднего звена (среднее профессиональное, среднее специальное); неполное высшее } \\
\text { профессиональное; высшее образование (бакалавр; специалист, магистр); подготовка кадров высшей } \\
\text { квалификации (послевузовское); не имею образования. Умение читать и писать: да; нет. }\end{array}$ \\
\hline 19 & $\begin{array}{l}\text { Укажите все имеющиеся у Вас источники средств к существованию: трудовая деятельность, включая } \\
\text { работу по совместительству; личное подсобное хозяйство; стипендия; пенсия (кроме пенсии по } \\
\text { инвалидности); пенсия по инвалидности; пособие (кроме пособия по безработице); пособие по } \\
\text { безработице; другой вид государственного обеспечения; сбережения, дивиденды, проценты; сдача }\end{array}$ \\
\hline
\end{tabular}


внаем или аренду имущества, доход от патентов, авторских прав; иждивение; помощь других лиц, алименты; иной источник (указать какой).

20 Какой из указанных источников средств к существованию Вы считаете для себя основным: записать номер источника из вопроса 19.

Заполняется для детей до 10 лет, не посещающих образовательную организацию

17 Посещает ли ребёнок дошкольную образовательную организацию: да; нет. Указать причину непосещения: нет мест; не хватает средств на оплату услуг; нет поблизости дошкольной образовательной организации; по состоянию здоровья; не устраивает качество услуг в доступной дошкольной организации; нет необходимости посещения; другое.

Заполняется на лиц 15 лет и более

21 Имели ли Вы какую-либо работу, приносящую заработок или доход, с 24 по 30 сентября 2015 года: да; нет.

22 Искали ли Вы работу в течение последнего месяца: да; нет. Если «да», то ответить на вопрос: если бы Вам предложили подходящую работу, то смогли бы Вы приступить к ней в ближайшие две недели: да; нет. Если «нет», то указать 1 главную причину: получил(а) работу и приступаю к ней в ближайшие 2 недели; нашел(а) работу и ожидаю ответа; занимался(лась) организацией собственного дела; ожидаю начала сезона; учусь; нахожусь на пенсии; занимаюсь уходом за больным; занимаюсь ведением домашнего хозяйства и/или воспитанием детей; по состоянию здоровья; нет возможности найти работу, нет необходимости работать; иная причина.

Для женщин в возрасте 15 лет и более

23 Сколько детей Вы родили, не считая мертворожденных.

Для мужчин в возрасте 18-59 лет и женщин в возрасте 18-44 лет

24 Сколько всего детей, включая уже имеющихся: собираетесь иметь; хотелось бы иметь при наличии всех необходимых условий.

25 Если Вы хотели бы иметь детей больше, чем собираетесь, то в какой степени рождению желаемого числа детей могли бы способствовать следующие условия (указать для каждого варианта степень значимости по шкале от 1 до 5): возможность получения ежемесячного пособия по уходу за ребенком до 3 лет; федеральный материнский (семейный) капитал; региональный материнский (семейный) капитал; возможность получения ежемесячной выплаты на 3 ребенка в размере прожиточного минимума; возможность получения без проблем место в детском саду; возможность получения налоговые льготы работающим родителям; предоставление семьям с 3 и более детьми земельных участков под строительство жилого дома; возможность иметь гибкий график работы; возможность профессиональной подготовки, переподготовки и повышения квалификации в период отпуска по уходу за ребенком до 3-х лет; изменение личных обстоятельств; повышение уровня жизни семьи; возможность при рождении 2 и последующего ребенка получить беспроцентную ссуду на покупку жилья площадью в размере соц. нормы.

26 Имеете ли Вы хронические заболевания, ограничивающие Вашу жизнедеятельность: да, нет.

27 Нужна ли Вам помощь другого человека для ежедневной деятельности в связи с Вашими ограничениями по состоянию здоровья: да; нет. Если «да», то указать, кто оказывает помощь: социальный работник; родные знакомые, проживающие в этом помещении; специально нанятый человек; родные, знакомые, проживающие отдельно (в т. ч. соседи)).

28 Установлена ли Вам сейчас группа инвалидности: да (1 группа; 2 группа; 3 группа; ребёнокинвалид); нет. 


\title{
POPULATION MICROCENSUSES IN RUSSIA: PAST, PRESENT AND FUTURE ANASTASIYA PYANKOVA, EKATERINA SCHERBAKOVA, SERGEY VASIN
}

\begin{abstract}
The paper traces the history of the three population microcensuses held in Russia in 1985, 1994 and 2015, highlighting their methodological, technological and operational aspects, as well the questionnaire's design. Given that the microcensuses provide more data in terms of new topics than conventional decennial population and housing censuses, this article focuses on the main research findings based on microcensus data.
\end{abstract}

A closer look is taken at the 2015 population microcensus, as it has peculiarities in terms of sample size and design, as well as at the content of the census questionnaires. Deviations of the regional-territorial structure of the sample from the permanent population of Russia are revealed.

It is shown that the representativeness of the data for the whole country is distorted, and the sociodemographic and geographical characteristics of the population are also biased due to the considerable variability of the sample size by regions of Russia. A comparison of the size and structure of the population according to the 2015 microcensus with data from vital statistics and population censuses, together with an estimate of age heaping, indicates serious problems with the data quality of the microcensus and the presence of typical errors common to conventional population censuses.

Attention is focused on a shifting of the age structure of the population to older ages according to the 2015 microcensus, which could affect figures on education, economic activity, morbidity, disability, the demographic composition of households and other variables closely related with age.

Key words: population micro-census history, micro-census topics, sample design, data quality.

Anastasiya I. Pyankova (apyankova@hse.ru), NAtional Research University Higher School of Economics, RUSSIA.

EKATERINA M. ScherbaKova (escherbakova@hse.ru), NATIONAL RESEARCH UnivERSiTy Higher SchOOL OF ECONOMICS, RUSSIA.

SERGEy A. VAsin (svasin@hse.ru), NATIONAL ReSEARCh University Higher School of Economics, Russia.

THE STUDY WAS IMPLEMENTED UNDER THE BASIC RESEARCH PROGRAM AT THE NATIONAL RESEARCH UNIVERSITY HIGHER SCHOOL OF ECONOMICS (HSE) IN 2017. PROJECT "THE LONG-TERM DEMOGRAPHIC DEVELOPMENT OF RUSSIA IN THE LIGHT OF THE 2015 MICROCENSUS RESULTS".

DATE RECEIVED : JUNE 2017.

\section{REFERENCES}

Andreev E.M. (2012). O tochnosti rezul'tatov rossiyskikh perepisey naseleniya i stepeni doveriya $\mathrm{k}$ raznym istochnikam informatsii [On the accuracy of the results of Russian population censuses and the level of confidence in different sources of information] // Voprosy statistiki [Statistical issues]. 11: 21-35.

Andreev E.M., G.A. Bondarskaya, T.L. Kharkova (1998). Padenie rozhdaemosti v Rossii: gipotezy i fakty [Fertility decline in Russia: hypotheses and facts] // Voprosy statistiki [Statistical issues]. 10: 82-93. 
Andreev E.M., G.A.Bondarskaya (2000). Mozhno li ispol'zovat' dannye ob ozhidaemom chisle detey $\mathrm{v}$ prognoze chislennosti naseleniya [Is it possible to use data on the expected number of children in the population projections] // Voprosy statistiki [Statistical issues]. 11: 56-62.

Andreev E.M., M.V. Rakhmaninova (1999). Vnutrennyaya migratsiya v Rossii: proshloe i nastoyashchee [Internal migration in Russia: past and present] // Voprosy statistiki [Statistical issues]. 5: 53-63.

Andreev E.M., S.V. Zakharov (2017). Mikroperepis' 2015 stavit pod somnenie rezul'tativnost' mer po stimulirovaniyu rozhdaemosti [2015 microcensus casts doubt the results of the pronatalist policy] // Demoscope Weekly [Demoscop Weekly]. 711-712. URL: http://www.demoscope.ru/weekly/2017/0711/tema02.php (accessed: 15.05.2018).

Andreev E.M., T.L. Kharkova (2013). Sravnitel'nyy analiz dannykh iz raznykh istochnikov o chisle rozhdennykh detey [Comparative analysis of data from various sources on the number of children born] // Voprosy statistiki [Statistical issues]. 5: 38-46.

Andreev E.M. (2001). Jews in Russia's Households (Based on the 1994 Microcensus) // Papers in Jewish Demography 1997 / S. Della Pergola, J. Even, eds. Jerusalem: The Hebrew University of Jerusalem: 141-159.

Barkalov N.B. (1997). Expected fertility as it appears from the 1994 microcensus a parityprogression dimension] // Population: the current state and prospects for the development of scientific knowledge. Collection of reports of the first Valantey conference. Moscow: 118-137.

Barkalov N.B. (1999). The fertility decline in Russia, 1989-1996: a view with period parityprogression rations // Genus. 55 (3-4): 11-60.

Barkalov N.B. (2005). Changes in the quantum of Russian fertility during the 1980s and early 1990s // Population and Development Review. 31(3): 545-556.

Baza mikrodannykh federal'nogo statisticheskogo nablyudeniya «Sotsial'no-demograficheskoe obsledovanie (mikroperepis' naseleniya) 2015 goda» [Database of microdata of the Federal statistical survey «Socio-demographic survey (population microcensus)» 2015] (2015). Rosstat. URL: http://vpnmicrodata.gks.ru/webapi/jsf/tableView/tableView.xhtml (accessed: 15.05.2018).

Belov I. (1986). O vyborochnom sotsial'no-demograficheskom obsledovanii naseleniya $1985 \mathrm{~g}$. [On the 1985 sample socio-demographic survey] // Vestnik statistiki [Statistical issues]. 9: 4045 .

Bondarskaya G.A. (1994). Ethnic-Territorial Differences in Marital Fertility: A 1985 Survey / Demographic Trends and Patterns in the Soviet Union Before 199 / W. Lutz, S. Scherbov, A. Volkov, eds. London and New York: Routledge: 71-87.

Bujard M., M. Scheller (2017). Impact of Regional Factors on Cohort Fertility: New Estimations at the District Level in Germany // Comparative Population Studies. 42: 55-88.

Chernysheva T.M. (1990). Metodologiya formirovaniya territorial'noy vyborki v SSSR [Methodology of the territorial sample in the USSR] // Kooperatsiya stran - chlenov SEV v statistike [Cooperation of CMEA member countries in statistics]. Vyp. 6 [Issue 6]. Moscow: Izd-vo SEV: 12-23.

Chislennost' naseleniya [Population] (2015). Statisticheskiy byulleten' «Chislennost' naseleniya Rossiyskoy Federatsii po polu i vozrastu 1 yanvarya 2015 goda» [Statistical Bulletin «Population of the Russian Federation by sex and age on January 1, 2015»]. Moscow: Rosstat. URL: http://www.gks.ru/bgd/regl/B15_111/Main.htm (accessed: 15.05.2018). 
Chislennost' naseleniya [Population] (2016). Statisticheskiy byulleten' "Chislennost' naseleniya Rossiyskoy Federatsii po polu i vozrastu 1 yanvarya 2016 goda» [Statistical Bulletin «Population of the Russian Federation by sex and age on January 1, 2016»]. Moscow: Rosstat URL: http://www.gks.ru/bgd/regl/B16_111/Main.htm (accessed: 15.05.2018)

Darsky L.E. (1994). Quantum and timing of births in the USSR / Demographic Trends and Patterns in the Soviet Union Before 1991 / W. Lutz, S. Scherbov, A.G. Volkov, eds. London and New York: Routledge: 57-69.

Darsky L.E., S. Scherbov (1990). Parity-progression fertility tables for the nationalities of the USSR. IIASA Working Papers, Laxenburg. WP-90-53.

Darsky L.E. (2005). Ozhidaemoe chislo detey u zhenshchin raznykh natsional'nostey i perspektivy rozhdaemosti $\mathrm{v}$ naselenii byvshego SSSR [The number of expected children by women of different nationalities and fertility prospects in the former USSR] // Demoscope Weekly [Demoscop Weekly]. 191-192. URL: http://www.demoscope.ru/weekly/2005/0191/nauka02.php (accessed: 30.05.2018).

Darsky L.E., I.P. Ilyina (1990a). Normalizatsiya brachnosti v SSSR [Nuptality normalization in the USSR]// Demograficheskie protsessy v SSSR [Demographic processes in the USSR] / Volkov A.G., ed. Moscow: Nauka: 6-27.

Darsky L.E., I.P. Ilyina (2000). Brachnost' v Rossii. Analiz tablits brachnosti [Nuptality in Russia. Analysis of nuptality tables] / A.G. Volkov, ed. Moscow: Informatika. 144 p.

Darsky L.E., I.P. Ilyina (1990b). Tablitsy brachnosti osnovnykh natsional'nostey soyuznykh respublik SSSR (Po dannym vyborochnogo obsledovaniya 1985 g.) [Nuptality tables of the main nationalities of the USSR republics (according to the sample survey1985)] // Ekonomika. Demograficheskaya statistika: Issledovaniya i problemy [Economy. Demographic statistics: Research and problems]. Moscow: Nauka: 206-210.

Doklad Rosstata [The Report of Rosstat] (2016). Ob osnovnykh itogakh federal'nogo statisticheskogo nablyudeniya «Sotsial'no-demograficheskoe obsledovanie (mikroperepis' naseleniya) 2015 goda» [On the main results of the Federal statistical survey «Sociodemographic survey (population microcensus) of 2015»]. URL: http://www.gks.ru/free_doc/new_site/population/demo/micro-perepis/finish/doklad.pdf (accessed: 12.05.2018).

Edin B., U. Rendtel (2007). Assessing the bias due to non-coverage of residential movers in the German Microcensus Panel: an evaluation using data from the Socio-Economic Panel // Advances in Statistical Analysis. 91(3): 311-334.

Isupov A.A. (1992). Programma sotsial'no-demograficheskogo obsledovaniya 1994 goda [The program of the socio-demographic survey 1994] // Vestnik statistiki [Statistical issues]. 9: 2528.

Itogi vyborochnogo sotsial'no-demograficheskogo obsledovaniya naseleniya 1985 (1986) [The results of sample socio-demographic survey 1985] // Vestnik statistiki [Statistical issues]. 7: 67-79; 8: 72-80; 9: 75-78.

Kharkova T.L., E.M. Andreev (2000). Did the Economic Crisis Cause the Fertility Decline in Russia: Evidence from the 1994 Microcensus // European Journal of Population. 16(3): 211233.

Kibele E., R. Scholz, V.M. Shkolnikov (2008). Low migrant mortality in Germany for men aged 65 and older: Fact or artifact // European Journal of Epidemiology. 23(6): 389-393. 
Kuznetsov L.R. (1990). Vzaimosvyaz' migratsii i brachnosti [The relationship of migration and nuptality] // Demograficheskie protsessy v SSSR [Demographic processes in the USSR]. Moscow: Nauka: 58-77.

Kuznetsov L.R. (1992a). Osobennosti matrimonial'nogo povedeniya migrantov [Peculiarities of the migrants' matrimonial behavior] // Migratsiya [Migration]. Demografiya i sotsiologiya [Demography and sociology]. Vyp. 2 [Iss. 2]. Moscow: 163- 180.

Kuznetsov L.R. (1992b). Statisticheskoe izuchenie vzaimosvyazi demograficheskikh protsessov i migratsii [Statistical study of the relationship between demographic processes and migration]: PhD Thesis. Moscow: Research Institute of statistics. 27 p.

Metodicheskie poyasneniya $\mathrm{k}$ sotsial'no-demograficheskomu obsledovaniyu (mikroperepis' naseleniya) 2015 goda [Methodological explanations to the socio-demographic survey (population microcensus) of 2015] URL: http://www.gks.ru/free_doc/new_site/population/demo/micro-perepis/finish/microperepis.html (accessed: 15.05.2018).

Mills M. (2000). The transformation of Partnerships. Canada, the Netherlands, and the Russian Federation in the Age of Modernity. Amsterdam: Thela Thesis. 278 p.

Mills M. (2004). Stability and change: the structuration of partnership histories in Canada, the Netherlands, and the Russian Federation // European Journal of Population. 20: 141-175.

Mkrtchjan N.V. (2012). Problemy ucheta naseleniya otdel'nykh vozrastnykh grupp v khode perepisi naseleniya 2010 g.: prichiny otkloneniy poluchennykh dannykh ot ozhidaemykh [Problems of population counting of specific age groups in the 2010 population census: the causes of the variances of the obtained data from the expected] // Demograficheskie aspekty sotsial'no-ekonomicheskogo razvitiya [Demographic aspects of socio-economic development] / M.B. Denisenko, ed. Vyp. 22 [Iss. 22]. Moscow: MAKS Press: 197-214.

Nikitina S.Yu. (2013). Ob organizatsionnykh i metodologicheskikh voprosakh vyborochnogo federal'nogo statisticheskogo nablyudeniya «Mikroperepis' naseleniya 2015 g. [On the organizational and methodological issues of the federal statistical survey «Population microcensus 2015»]. Prezentatsiya doklada na rasshirennom zasedanii kollegii Rosstata 12.02.2013 [Paper presented at the extended meeting of the Rosstat Board in 12.02.2013]. URL: http://www.gks.ru/free_doc/new_site/rosstat/smi/smi-1302.html (accessed: 21.11.2017).

Nikitina S.Yu. (2015). Ob organizatsionnykh i metodologicheskikh voprosakh vyborochnogo federal'nogo statisticheskogo nablyudeniya «Mikroperepis' naseleniya 2015» [On the organizational and methodological issues of the federal statistical survey «Population microcensus 2015»] // Voprosy statistiki [Statistical issues]. 3: 35-37.

Osnovnye itogi mikroperepisi naseleniya 1994 g. v 8 tomakh [The main results of the 1994 population microcensus in 8 volumes] (1995). Moscow: Gosudarstvennyy komitet Rossiyskoy Federatsii po statistike.

Population (2017). Statisticheskiy byulleten' «Chislennost' naseleniya Rossiyskoy Federatsii po polu i vozrastu 1 yanvarya 2017 goda» [Statistical Bulletin «Population of the Russian Federation by sex and age on January 1, 2017»]. Moscow: Rosstat URL: http://www.gks.ru/bgd/regl/b17_111/Main.htm (accessed: 15.05.2018).

Population census history in Russia (2013). Moscow: Golden Bi. 414 p.

Pyankova A. I. (2015). Traditsionnyy i al'ternativnye metody provedeniya perepisey naseleniya [Traditional and alternative census methods]. PhD Thesis. Moscow: Higher school of Economics. 
Ramonov A.V., A.I. Pyankova (2014). Izuchenie zdorov'ya: potentsial perepisey naseleniya [Evaluating public health on the basis of census information] // Demograficheskoe obozrenie [Demographic review]. 1(2): 140-155.

Scherbov S., van Vianen H. (1999). Marital and Fertility Careers of Russian Women Born between 1910 and 1934 // Population and Development Review. 25 (1): 129-143.

Scherbov S., van Vianen H. (2001). Marriage and Fertility in Russia of Women Born between 1900 and 1960: A Cohort Analysis // European Journal of Population. 17(3): 281-294.

Scherbov S., van Vianen H. (2002). Period Fertility in Russia since 1930: an application of the Coale-Trussell fertility model // Demographic Research. 6: 455-470.

Scherbov S., van Vianen H. (2004). Marriage in Russia: a reconstruction // Demographic Research. 10: $27-60$.

Soroko E. (2001). Jewish Households in Russia according to the 1994 Microcensus // Papers in Jewish Demography 1997 / S. Della Pergola, J. Even, eds. Jerusalem: The Hebrew University of Jerusalem: 161-179.

Svodnye rezul'taty otsenki reprezentativnosti blokov tablits s itogami mikroperepisi naseleniya 2015 goda [The representativeness of the tables with the results of the 2015 population microcensus] (2015). URL: http://www.gks.ru/free_doc/new_site/population/demo/microperepis/finish/micro-perepis.html (accessed: 15.05.2018).

Tablitsy s itogami federal'nogo statisticheskogo nablyudeniya «Sotsial'no-demograficheskoe obsledovanie (mikroperepis' naseleniya) 2015 goda» [Tables with the results of the Federal statistical survey «Socio-demographic survey (population microcensus) 2015»] (2015). URL: http://www.gks.ru/free_doc/new_site/population/demo/micro-perepis/finish/microperepis.html (accessed: 15.05.2018).

Tolts M. (1996). The Jewish Population of Russia, 1989-1995 // Jews in Eastern Europe. 3(31): 519.

Tolts M. (1997). The Interrelationship between Emigration and the Socio-Demographic Profile of Russian Jewry / N. Lewin-Epstein, Y. Ro'i, P. Ritterband, eds. Russian Jews on Three Continents. London: Frank Cass: 147-176.

Tolts M. (1998). Recent Jewish Emigration and Population Decline in Russia // Jews in Eastern Europe. 1(35): 5-24.

Tolts M. (1999). Yiddish in the Former Soviet Union Since 1989: A Statistical-Demographic Analysis // G. Estraikh, M. Krutikov, eds. Yiddish in the Contemporary World. Oxford: European Humanities Research Centre, University of Oxford. 133-146.

Vishnevskiy A.G., S.V. Zakharov (2010). Chto znaet i chego ne znaet rossiyskaya demograficheskaya statistika [What know and doesn't know Russian demographic statistics] // Voprosy statistiki [Statistical issues]. 2: 7-17.

Volkov A.G. (1984). Pervaya mikroperepis' naseleniya SSSR [The first microcensus of the USSR population] // Zdravookhranenie Rossiyskoy Federatsii [Health care of the Russian Federation]. 10: 3-6.

Volkov A.G. (1999a). New features of family formation and composition: case of Russia // Revue Baltique. Vilnius. 13: 82-96.

Volkov A.G. (1999b). Methodology and Organization of the 1994 Microcensus in Russia. Population Research Centre, University of Groningen. Working Paper 99-5. 
Volkov A.G. (2014a). Metodologiya i organizatsiya mikroperepisi v Rossii v 1994 g. [Methodology and organization of the 1994 Microcensus in Russia] // Izbrannye demograficheskie trudy [Selected Works on Demography: a collection of scientific articles] /A.G. Vishnevsky, ed. Moscow: HSE Publishing House: 180-198.

Volkov A.G. (2014b). Novye osobennosti formirovaniya sem'i i ee sostav: primer Rossii [New features of family formation and its composition: the example of Russia] // Izbrannye demograficheskie trudy [Selected Works on Demography: a collection of scientific articles] / A.G. Vishnevsky, ed. Moscow: HSE Publishing House: 432-447.

Volkov A.G. (2014c). Etnicheski smeshannye sem'i v SSSR: dinamika i sostav [Ethnically mixed families in the USSR: dynamics and composition] // Izbrannye demograficheskie trudy [Selected Works on Demography: a collection of scientific articles] / A.G. Vishnevsky, ed. Moscow: HSE Publishing House: 405-431.

Volkov A.G., E.L. Soroko (1999). Tipologiya semey i domokhozyaystv v Rossii: razvitie i analiz (po dannym mikroperepisi 1994 goda) [Family and household typology in Russia: development and analysis (according to the 1994 microcensus)] // Voprosy statistiki [Statistical issues]. 5: 40-52.

Wiedenhofer B. (2000). Assistance for/ by women and men aged 60 years or more. Paper presented at the Conference of European Statisticians (Italy, Orvieto, 11-13 October 2000). URL: http://www.unece.org/fileadmin/DAM/stats/documents/2000/10/gender/12.e.pdf (accessed: 15.05.2018).

Zakharov S.V. (2006). Vozrast vstupleniya v pervyy brak [Age at first marriage]/ Demograficheskaya modernizatsiya Rossii, 1900-2000 [Demographic Modernization, 19002000] / A.G. Vishnevskiy, ed. Moscow: Novoe izdatel'stvo: 107-120.

Zukula B. (2016). Methodology of estimating the annual number of usual resident population in Latvia // Paper presented at the Conference of European Statisticians (Switzerland, Geneva, 18-20 May 2016). URL: http://www.unece.org/fileadmin/DAM/stats/documents/ece/ces/ge.10/2016/mtg2_WS/23_Lat via_BZukula_ENG.pdf (accessed: 15.05.2018). 